\title{
Il secondo concorso per il Parlamento di Ernesto Basile. Analisi e ricostruzione congetturale
}

Fabrizio Avella

Abstract

Lo studio si inquadra nel settore delle ricostruzioni congetturali di progetti a partire da disegni di archivio. Nel caso specifico, si tratta del progetto di Ernesto Basile per il secondo concorso per il Parlamento del Regno d'Italia, conclusosi nel 1889.

Ė un progetto molto maturo, premiato dalla Commissione giudicatrice ex aequo insieme ad altri quattro, e conclude la fase dei concorsi romani (1882-89), segnata da un linguaggio classicista che permea i progetti per le sedi istituzionali.

I disegni originari dell'opera, non realizzata, sono conservati presso la Dotazione Basile-Ducrot del Dipartimento di Architettura dell'Università di Palermo, e sono stati utilizzati per il rilievo, la vettorializzazione, l'analisi e la modellazione tridimensionale.

Sono stati elaborati modelli analogici, volti ad offrire una lettura grafica in grado di enucleare aspetti compositivi, e modelli con finalità descrittiva per visualizzare spazi e volumi.

Parole chiave

storia del disegno, ricostruzione congetturale, tecniche di rappresentazione.

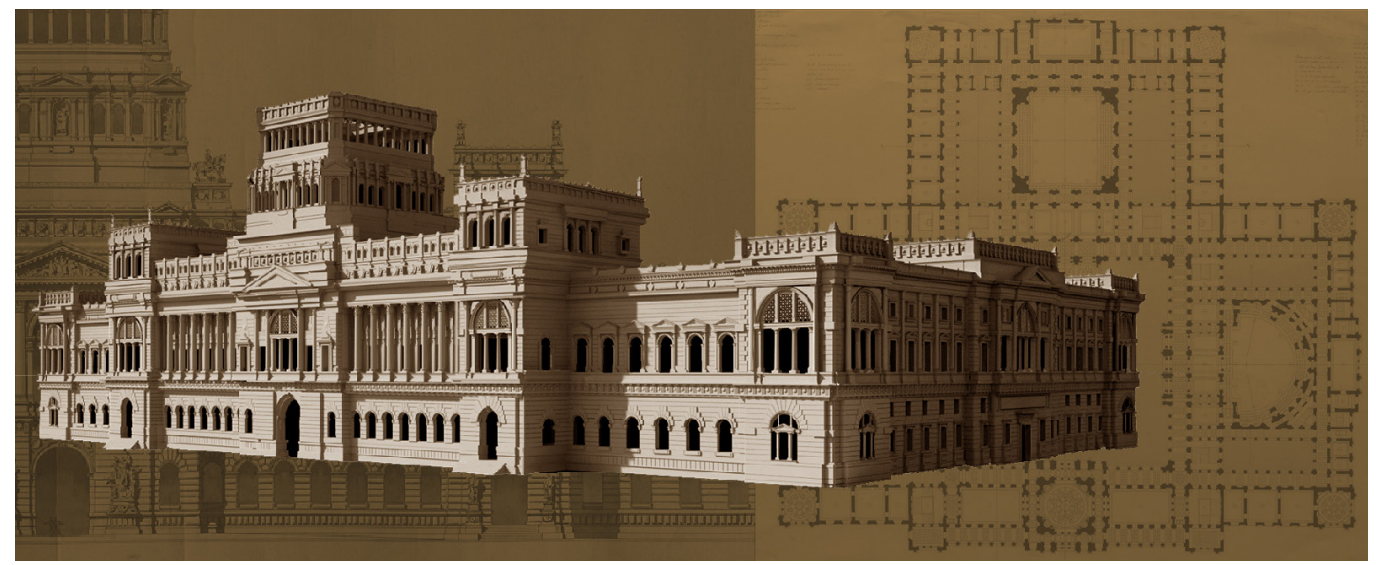




\section{Introduzione}

Il progetto per il secondo concorso per il Parlamento del Regno d'Italia (I 888-89) può essere considerato uno più importanti della produzione di Ernesto Basile e si inserisce nella produzione romana dei progetti di concorso per le nuove sedi istituzionali del giovane Regno d'Italia. II "moderno classicismo" [Sessa 2002] che li caratterizza, è declinato, di volta in volta, in base ad esigenze linguistiche e funzionali.

Basile inizia a confrontarsi, appena ventiseienne, con la complessità dei temi elaborando il progetto per il primo concorso per il Palazzo del Parlamento (1883) in cui manifesta un controllo compositivo che colpisce data la sua giovane età.

L'anno successivo elabora il progetto per il primo concorso per il Palazzo di Giustizia: permeato da un linguaggio ispirato alla "compiuta maturità espressiva" del Quattrocento fiorentino [Mauro, Sessa 20 15], presenta alcune asimmetrie planimetriche che saranno risolte nei progetti successivi. Nei progetti per il secondo ed il terzo concorso per il Palazzo di Giustizia (1885-1886), infatti, la variazione della composizione planimetrica e l'ispirazione ad un classicismo cinquecentesco danno luce ad organismi articolati con una coerenza progettuale che porta la Commissione a selezionare il progetto per la stesura del quarto concorso (1887). Qui Basile mette in discussione l'assunto compositivo ed inserisce un grande cortile centrale circondato da gallerie, tracciando una soluzione che sarà riproposta successivamente.

Fig. I. Corpus dei disegni: piante in scala $1: 200 \mathrm{e}$ piante 100 .

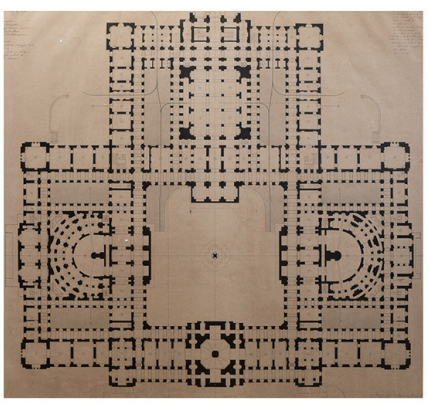

Pianta del seminterrato.
Matita china, inchiostro eacquerello su cartoncino.
Scala $1: 200.1088 \times 1132 \mathrm{~mm}$.

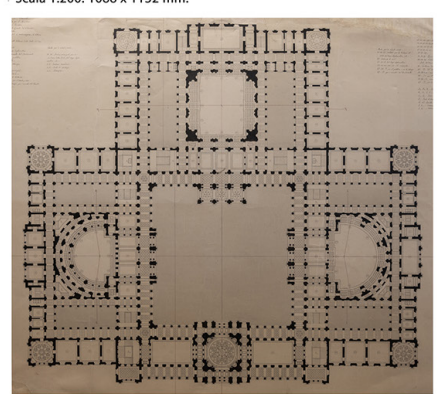

Pianta del primo piano.

Pianta del primo piano.
Matita, china, inchiostro e acq
Scala 1:200. $1043 \times 1134 \mathrm{~mm}$.

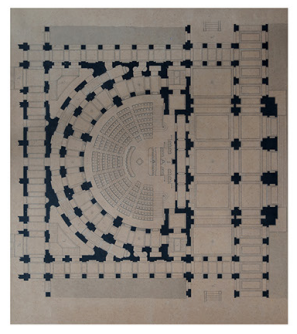

Pianta del dell'aula del Senato.

sucartonicio.
Scala $1: 100.758 \times 678 \mathrm{~mm}$.

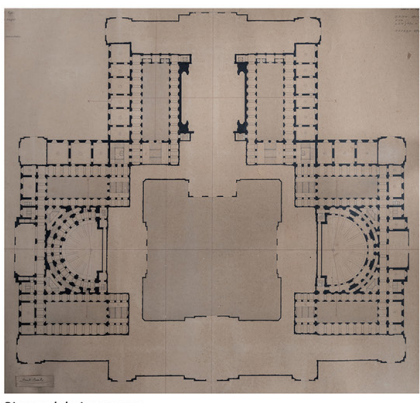

Pianta del piano terra. Matita, china, inchiostro e acquerello su cartoncino.
Scala 1:200.973 1095 mm

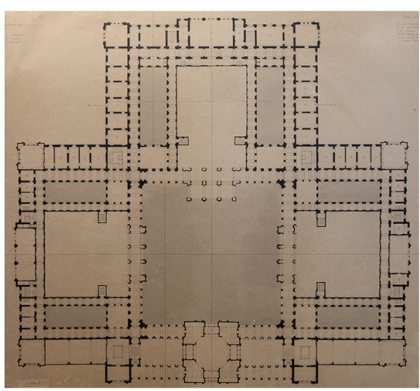

Pianta del secondo piano

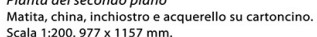

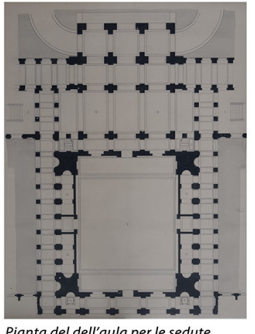

Pianta del dell'aula per le sedute

reali.
Matita, china, inchiostro e acquerello su cartoncino.
Scala 1:100. $828 \times 609 \mathrm{~mm}$.

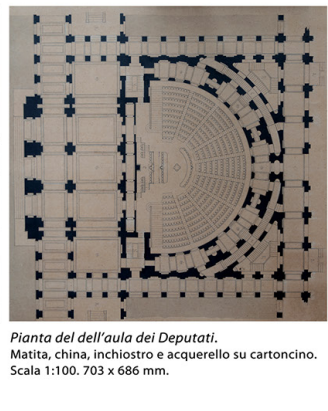


II progetto non risulta vincitore [I], ma l'esperienza accumulata gli consente di affrontare il secondo concorso per il Parlamento (I 888-89) con una maturità progettuale che sarà particolarmente apprezzata dalla giuria.

La Commissione giudicatrice, presieduta da Francesco Boschi, premia ex aequo i progetti di Ernesto Basile, Luigi Broggi e Giuseppe Sommaruga, Gaetano Moretti, Pier Paolo Quaglia e Vincenzo Benvenuti, Enrico Ristori [2].

II progetto non sarà realizzato per la crisi politica conseguente alla caduta del Governo presieduto da Francesco Crispi il 3 I gennaio I89 I ma presenta, in embrione, soluzioni che saranno adottate nell'ampliamento di Palazzo Montecitorio, che impegnerà Basile tra il 1903 e il 1918.

I disegni del progetto in esame sono conservati presso la Dotazione Basile delle Collezioni Scientifiche del Dipartimento di Architettura dell'Università degli Studi di Palermo, curato dal Professore Ettore Sessa.

Già da una prima osservazione si rimane colpiti dal forte rigore compositivo: un grande cortile centrale su cui affacciano l'Aula dei Deputati e quella del Senato, disposte simmetricamente rispetto all'asse principale, e l'Aula delle Sedute Reali, che chiude il cortile lungo l'asse di simmetria principale.

Il linguaggio utilizzato è ispirato ad un classicismo di matrice rinascimentale, molto austero ma opportunamente articolato nelle singole soluzioni compositive. La volumetria evidenzia con chiarezza lo schema compositivo ed il trattamento dei fronti è estremamente coerente con la gerarchia delle funzioni.

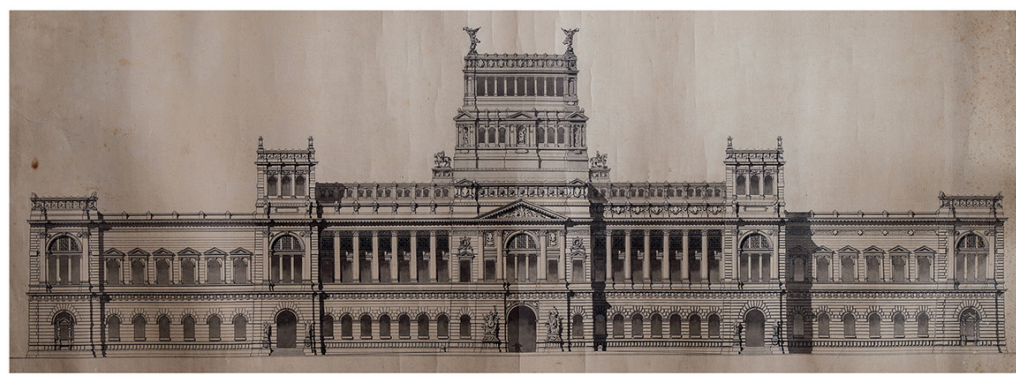

Prospetto principale.

Matita, china ed acquerello su cartoncino. Scala 1: $200.810 \times 1186 \mathrm{~mm}$.

Prospetti laterali.

Matita, china e acquerello su cartoncino. Scala 1:200. $928 \times 1181 \mathrm{~mm}$

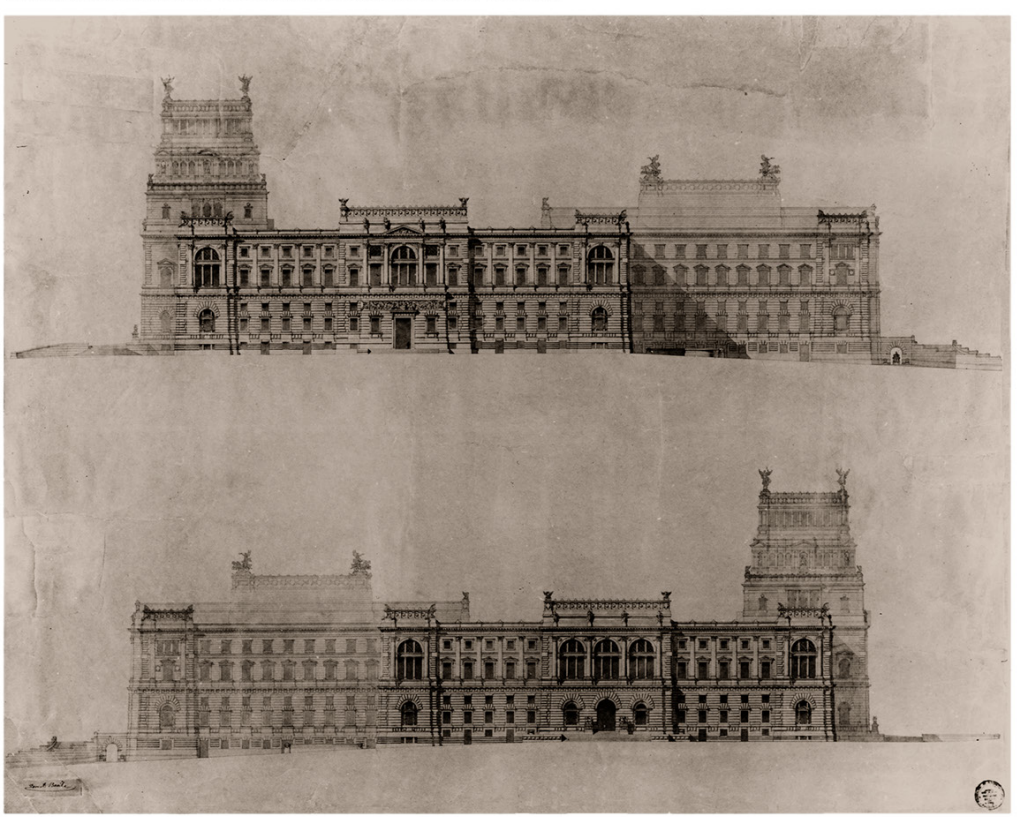




\section{Analisi delle fonti e vettorializzazione}

II corpus dei disegni contiene II tavole di grande formato, dal 70,5 per 68,2 cm. dell'inquadramento topografico fino agli 81,0 per $187,6 \mathrm{~cm}$. del prospetto principale. Sono presenti: una planimetria in scala I: 1000; quattro piante ai vari livelli, inchiostrate su cartoncino, in scala 1:200; tre piante, dell'Aula dei Deputati, dell'Aula del Senato e dell'Aula delle Sedute Reali, inchiostrate su cartoncino, in scala 1:100; il prospetto principale, ad inchiostro ed acquerello in scala I: I00; il prospetto posteriore e la sezione trasversale, a matita ed inchiostro su cartoncino, in scala I:200; i prospetti laterali, a matita, inchiostro ed acquerello su cartoncino, in scala $1: 200$.

L'analisi delle fonti documentarie ha evidenziato che le informazioni disponibili consentissero l'operazione di ricostruzione del progetto ed il parallelo processo di analisi.

Le scansioni piane dei disegni, fornite dalla Dotazione Basile, sono state utilizzate per realizzare il rilievo diretto per ricavare informazioni dimensionali, di massima e di dettaglio, relative ad interassi, moduli, spessori murari, aperture, modanature, necessarie per una corretta elaborazione del modello. Operazioni di fotogrammetria piana hanno, successivamente, consentito di correggere le distorsioni, per quanto minime, delle scansioni.

Le immagini ricavate sono state utilizzate per la vettorializzazione piana, condotta nel rispetto delle unità di misura metrico decimali, già in uso al momento della stesura del progetto [3], e della scansione modulare, non elaborata a posteriori ma utilizzata già in fase di dimensionamento degli elaborati: laddove l'identificazione di un modulo fosse chiara ed inequivocabile, in presenza di dubbi, si è data priorità al posizionamento in base ai moduli.

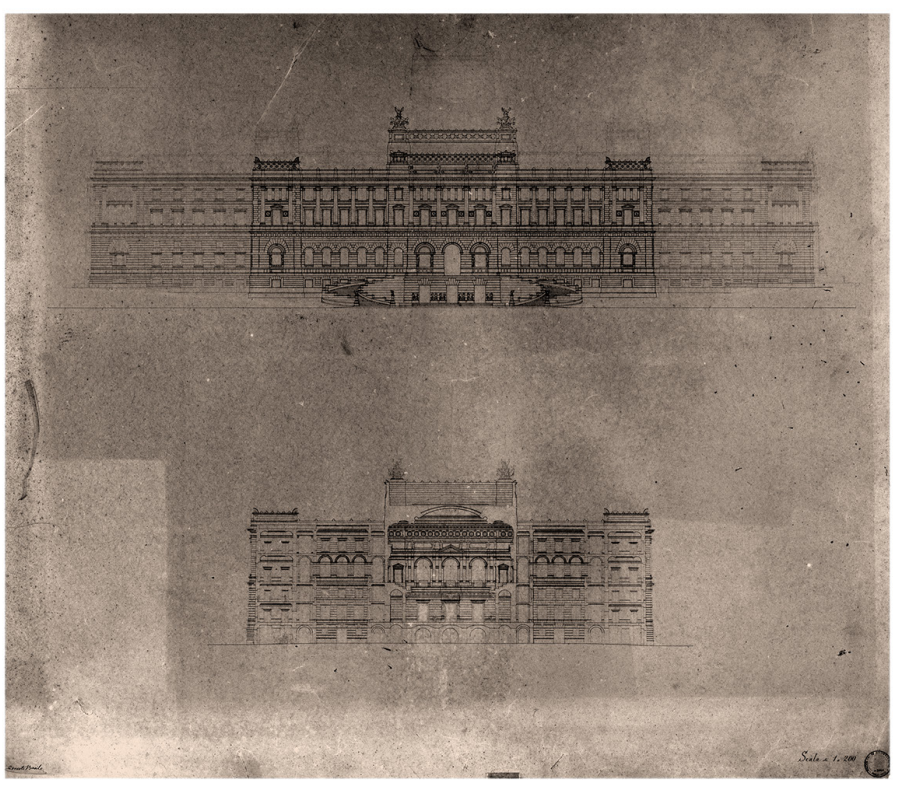

Prospetto posteriore
e sezione trasversale e sezione trasversale. Matita e china su cartoncino.
Scala 1:200. $1012 \times 1131 \mathrm{~mm}$.
Sezione longitudinale e sezione trasversale. Dal manifesto di presentazione
del progetto.

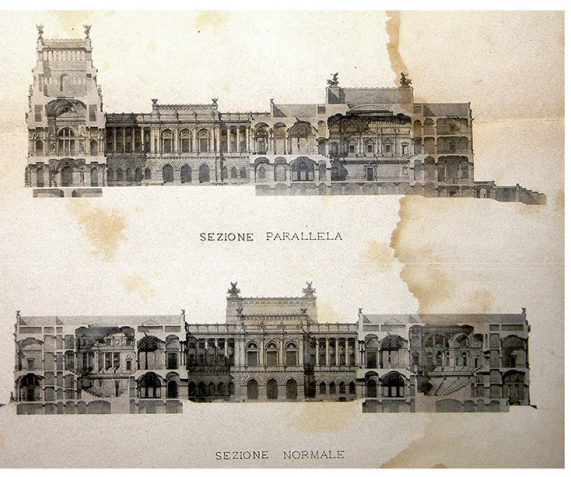




\section{Criteri d'interpretazione per la modellazione tridimensionale}

La costruzione del modello tridimensionale [4] ha rispettato il posizionamento degli assi compositivi, gli allineamenti planimetrici ed altimetrici dei comparti murari e delle aperture, nonché le partiture dell'ordine classico; in alcuni casi, anche se la documentazione iconografica era ampia e dettagliata, si sono operati criteri d'interpretazione logico-deduttiva nel caso di insufficienza di informazioni [5].

Per l'Aula delle Sedute Reali, ad esempio, l'assenza della pianta delle coperture non chiariva la configurazione del lucernario sommitale: si era ipotizzata una forma rettangolare, ritenuta congruente con l'impianto della sala, ma nella sezione trasversale si osserva la proiezione dell'ombra ad andamento ellittico del foro sommitale, che ha permesso di ipotizzarne la forma circolare, con pochi margini di dubbio [6]. L'ombra si è rivelata, dunque, presenza rivelatrice della forma [7].

Un altro problema di interpretazione è stato affrontato nella ricostruzione del fronte interno dell'Aula dei Deputati. Non vi sono disegni in cui è visibile, ma è possibile formulare un'ipotesi di configurazione prendendo spunto dalle tracce planimetriche e dalla morfologia dei vani contigui. II vestibolo adiacente è coperto da tre volte a crociera rialzate, che tracciano sui muri perimetrali i segni di grandi arcate: è ipotizzabile, dunque, che questi archi abbiano i loro corrispondenti sul fronte opposto del paramento murario, il cui raggio è desumibile dalla posizione delle colonne e delle semicolonne. II posizionamento dei tre archi sopra la trabeazione presente all'interno dell'Aula dei deputati definisce il fronte interno con una configurazione congruente sia con quella dell'aula, sia con quella del vestibolo. II tema della parete a tre fornici è, peraltro, sviluppato nel progetto definitivo che struttura la configurazione odierna della Camera dei Deputati. La soluzione proposta risulta, dunque, allo stato attuale delle conoscenze, plausibile.

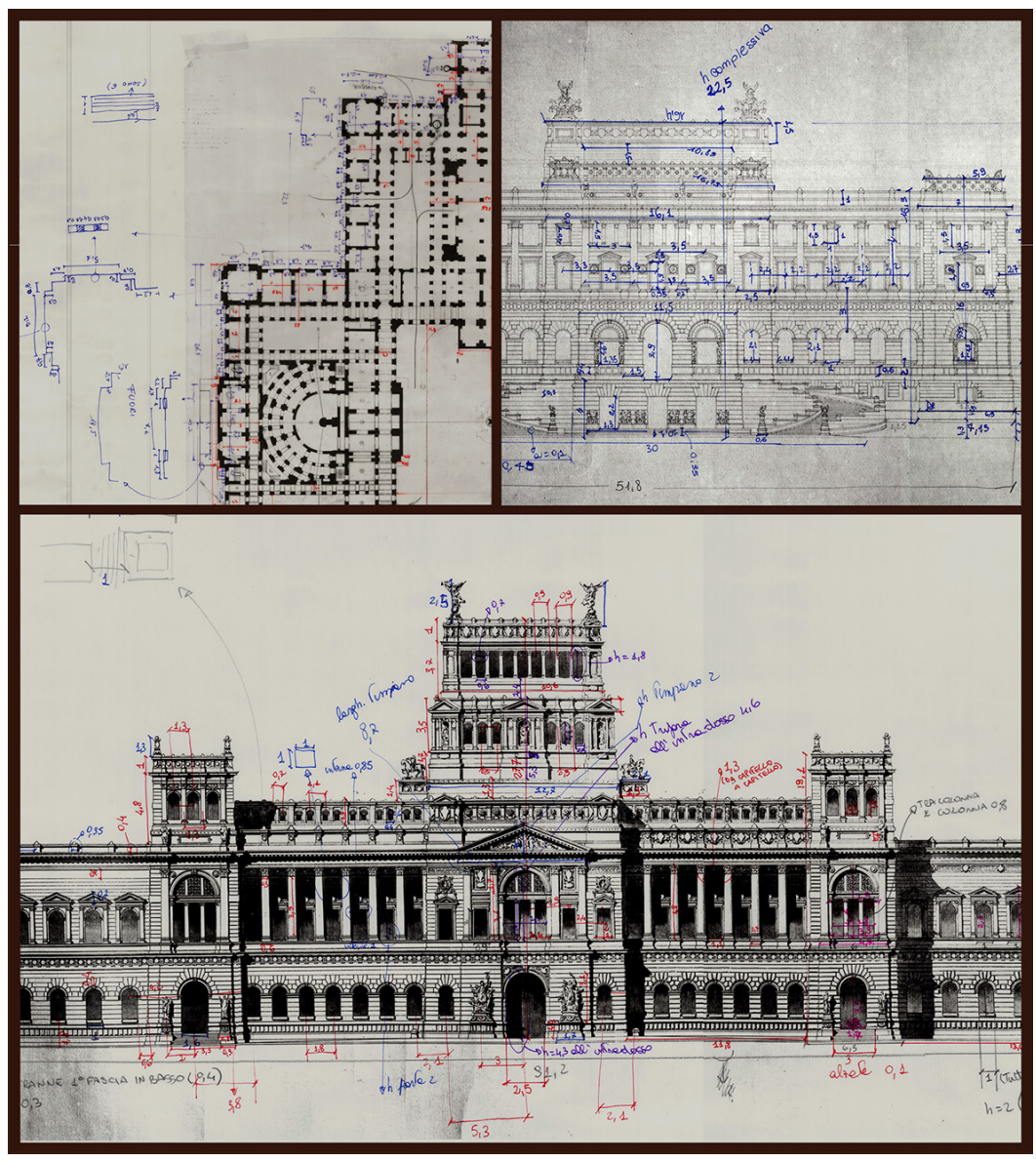


Altre informazioni mancanti sono relative al fronte del cortile retrostante l'ingresso: il fronte antistante l'Aula delle Sedute Reali è visibile in quella che Basile nomina "Sezione normale", quello antistante l'Aula del Senato è visibile nella "Sezione parallela" e quello dell'Aula dei Deputati lo si desume grazie alla perfetta simmetria dell'edificio, ma di quello retrostante l'ingresso non vi sono disegni. Vi sono, però, preziose informazioni desumibili dalle piante e dalle sezioni: l'avancorpo a torre dell'ingresso principale presenta una perfetta simmetria speculare, sia nelle piante che nella sezione longitudinale, che suggerisce la costruzione del fronte sul cortile per analogia; le ali colonnate che lo affiancano possono essere trattate come quelle visibili nelle sezioni originarie del cortile, ed essendo del tutto analoghe a quelle del fronte principale, e non vi è motivo di ipotizzare delle variazioni.

\section{Descrizioni analitiche}

I disegni con funzione analitica consentono quella che Giuseppe Pagnano definisce "lettura critica" di un progetto [Pagnano 1975], in cui l'architettura è assimilata al linguaggio e l'interpretazione al metalinguaggio: "Considerando l'architettura un insieme di segni, è possibile [...] definire il disegno come linguaggio applicato, come metalinguaggio dell'architettura" [Pagnano 1975, p. 7].

La rappresentazione è, in questo caso, ad alto contenuto simbolico [de Rubertis 2002],"con valenza analitico-informativa o semiotico-comunicativa" [8], e dissocia le componenti per poi ricomporle in immagini di sintesi: "Nella lettura critica la scomposizione viene effettuata mediante lo strumento grafico; quindi è l'immagine grafica dell'oggetto che viene dissociata in immagini parziali" [9].

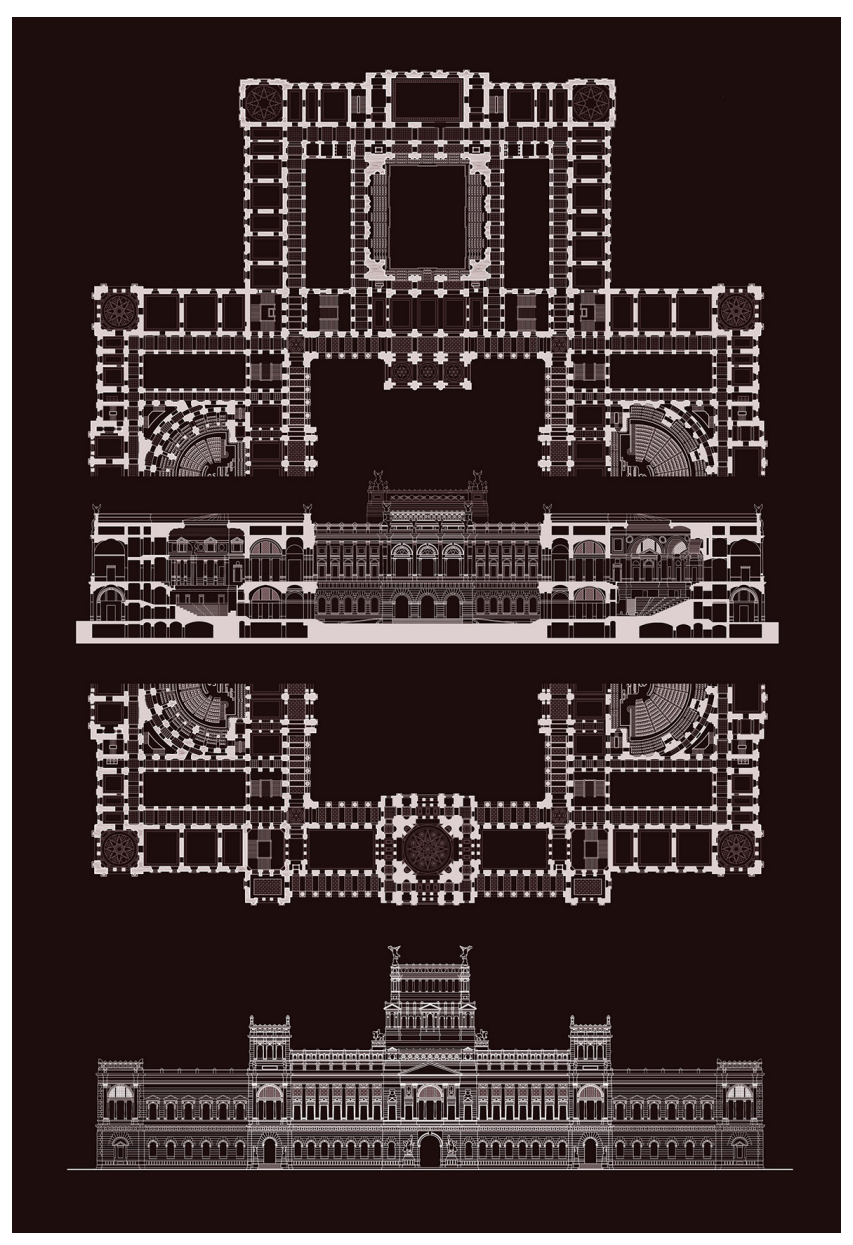


Fig. 6. Analisi delle

funzioni, dei percorsi, de

moduli e delle masse

murarie.

- scale secondarie

(3) AscensorI

(1) INGRESSI PRINCIPAL 1) INGRESSI SECONDARI

L. LOGGE

(v) VESTIBOL

--. ASSI COMPOSITIVI PRINCIPALI

-.-. ASSI COMPOSITIVI SECONDARI

-. ASSI DISTRIBUTIVI PRINCIPALI

..... ASSI DISTRIBUTIVI SECONDARI

$\bigcup_{c c}$ MODUL

MASSE MURARIE

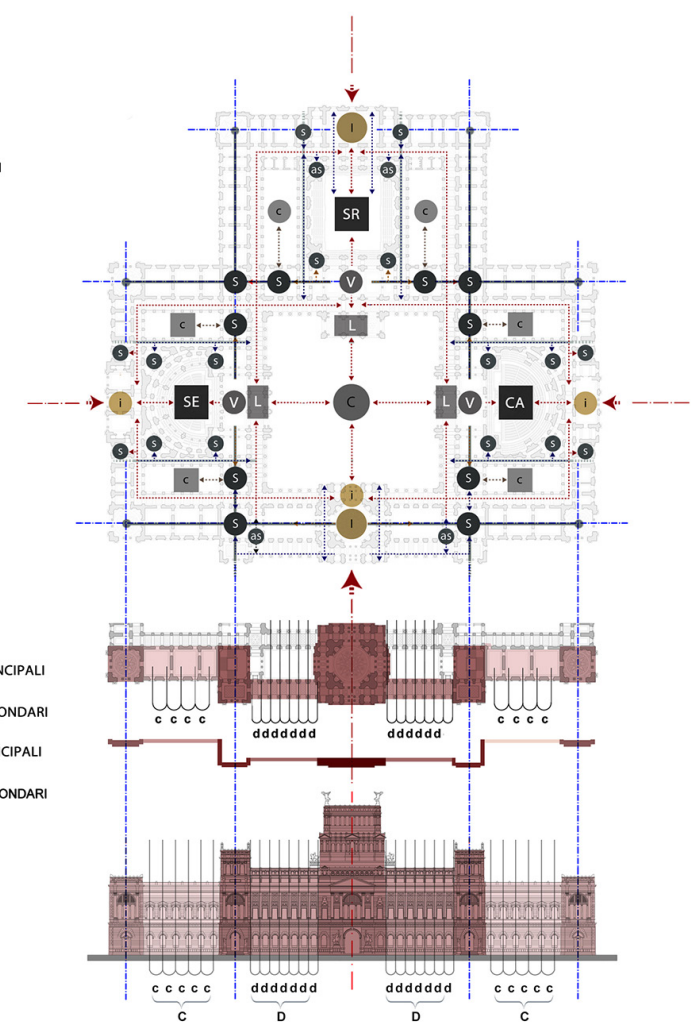

aule parlamentari

$\square$ GALLERIE

$\square$ CORPI SCALA PRINCIPAL

$\square$ CORPI SCALA SECONDARI

$\square$ FUNZIONI ACCESSORIE

$\square$ VESTIBOLI

$\square$ LOGGE

MASSA PRIMARIA

EZION

MASSA SECONDARIA
IN PRIMA PROIEZIONE

MASSA TERZIARIA IN

MASSA SECONDRIA IN
SECONDA PROIEZIONE

MASSA TERZIARIA IN

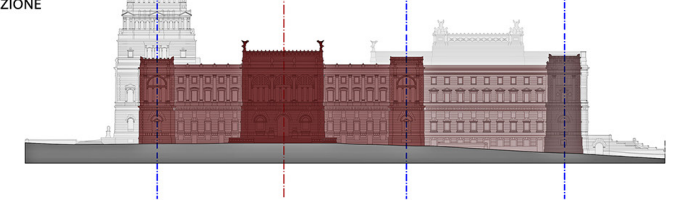


Fig. 8. Vista prospettica del fronte principale (modelazione e rendering: Carla Verace, post produzione dell'autore).

Fig. 9.Vista prospettica de fronte prospicente l'Aula dei Deputati (modellazione e render di Davide dell'autore).

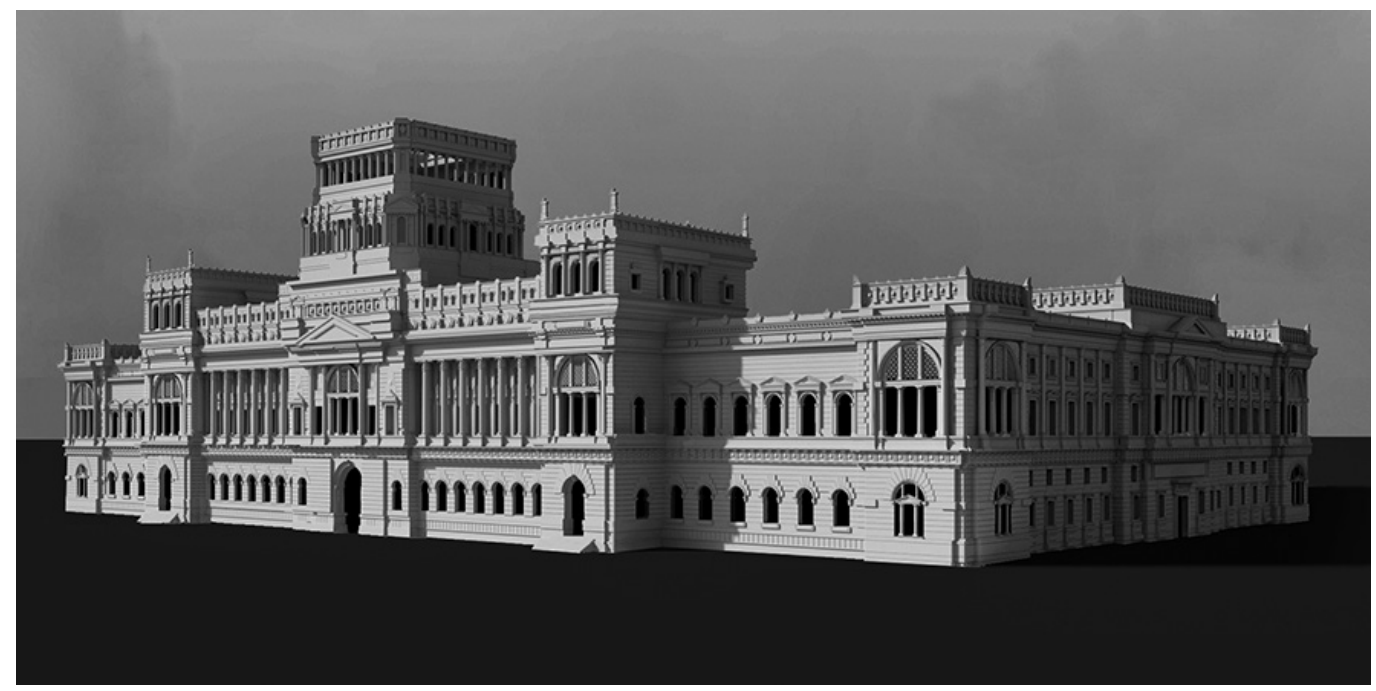

Come già accennato, lo schema compositivo si basa sulla giustapposizione di tre corpi, contenenti le aule, intorno al cortile centrale secondo una rigorosa simmetria speculare lungo l'asse longitudinale. II sistema è connesso da assi distributivi principali e secondari che collegano le aule, il cortile e le funzioni accessorie. Tutta la composizione è controllata da assi di simmetria principali e secondari e da un rigoroso sistema modulare.

In corrispondenza delle aule sono presenti sottosistemi di loggiati doppi che si affacciano sul cortile, mentre sull'intersezione degli assi distributivi vi sono i sistemi di salita principali e secondari.

La struttura funzionale è palesata con estrema coerenza dai partiti volumetrici. II fronte principale è tripartito verticalmente: l'avancorpo a torre dell'ingresso, che ha soltanto il ruolo di marcare l'edificio a livello urbano, è fiancheggiato da due ali colonnate chiuse da torrini angolari, posti all'intersezione delle ali laterali che ospitano le funzioni accessorie.

Questi ultimi fungono da cerniera con i fronti laterali, anch'essi caratterizzati da avancorpi leggermente aggettanti in corrispondenza delle aule, fiancheggiati da ali finestrate con ordine gigante.

La presenza delle aule è sottolineata, su tutti i fronti, oltre che dal leggero aggetto, da un maggiore sviluppo altimetrico e dal muro d'attico più sviluppato in altezza.

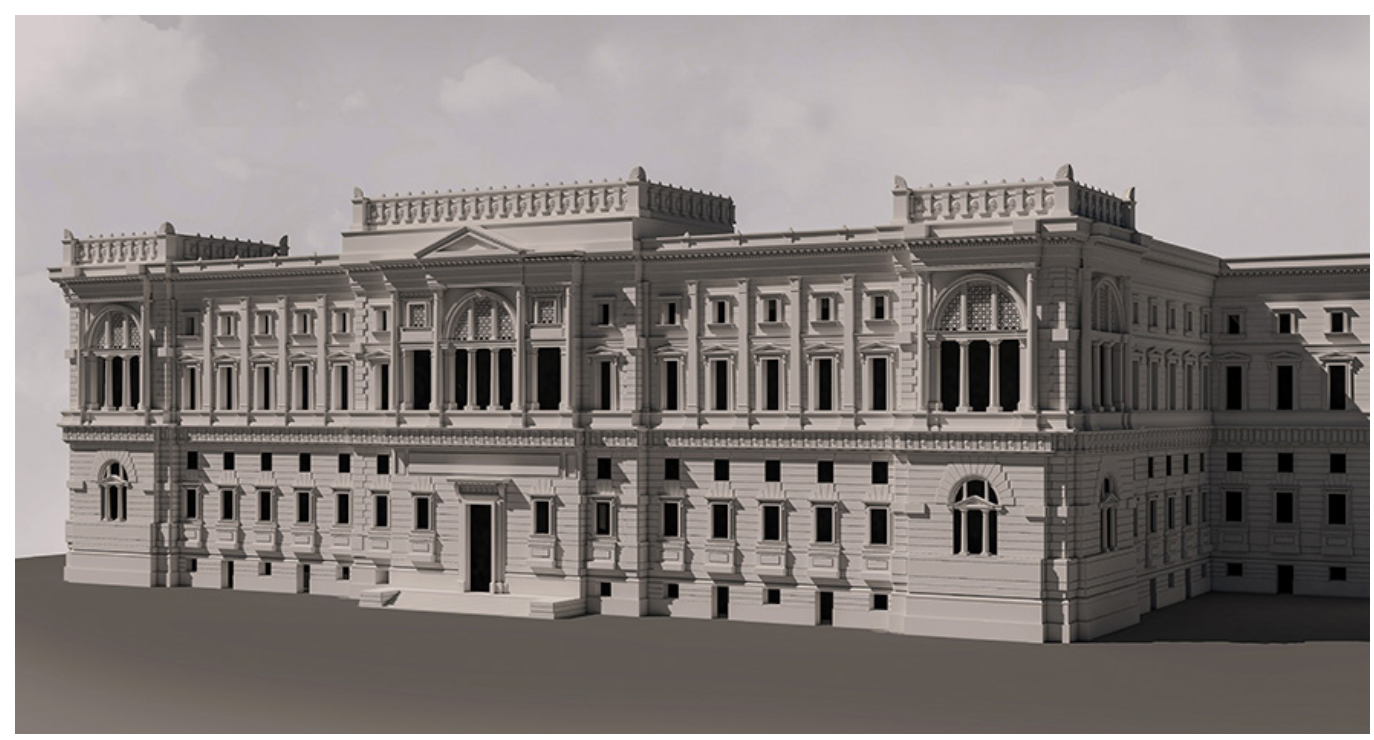


Fig. 10.Vista prospettica del fronte posteriore (modellazione e render di Irene Accurso; post produzione dell'autore).
II fronte posteriore è caratterizzato dalla sporgenza del volume dell'Aula per le Sedute Reali ed è articolato, analogamente al fronte principale, in due ali con paraste giganti a livello dell'aula chiuse da torrini angolari. II ruolo, gerarchicamente dominante, dell'aula, è sottolineato dalla monumentale scalinata a tenaglia.

Anche i fronti del cortile denunciano la presenza delle aule grazie ad aggetti in corrispondenza delle logge di accesso.

Tutto il perimetro murario è trattato secondo un sistema gerarchico molto forte: sul fronte anteriore l'ingresso alla principale istituzione del paese è trattato con l'enfasi monumentale che merita, i due fronti laterali rivelano l'equivalenza politica dell'Aula dei Deputati e dell'Aula del Senato, mentre il fronte posteriore sottolinea la presenza dell'Aula per le Sedute reali.

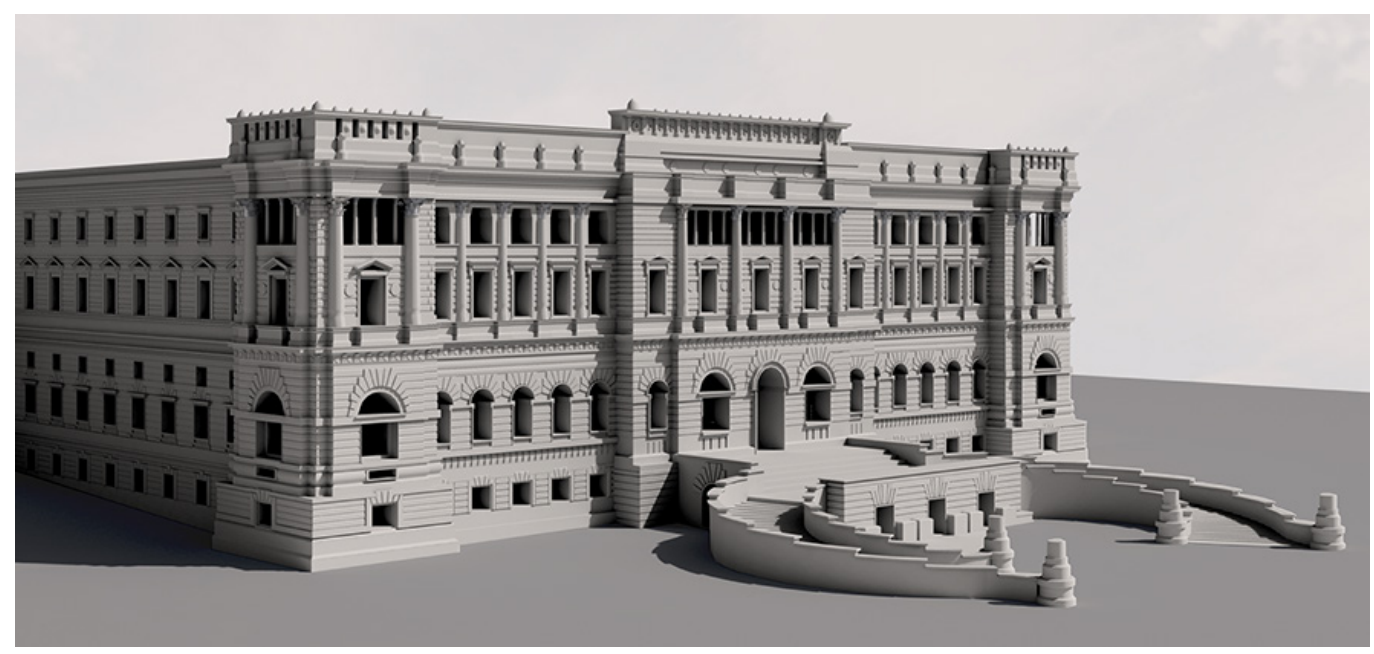

Viste prospettiche e tecniche di rappresentazione

A differenza degli elaborati di concorso per il Palazzo di Giustizia, tra i disegni originari non vi sono viste prospettiche. La mancanza è da sottolineare, visto che Basile, in tutta la sua attività progettuale, ne fa un largo uso. La ricostruzione del modello ha consentito, quindi, di visualizzare gli spazi e le declinazioni volumetriche dei fronti.

Si è scelto di eseguire prospettive a quadro verticale, con altezze del punto di vista variabili. Le prospettive degli esterni fanno apprezzare il forte senso di monumentalità che caratterizza l'edificio dell'istituzione politicamente più prestigiosa del Regno, nonché la sapiente articolazione di aggetti e arretramenti che manifestano, all'esterno, le gerarchie funzionali.

Lo spaccato prospettico sull'Aula delle Sedute Reali fa apprezzare sia lo spazio, sviluppato su una quadrupla altezza, sia il confronto linguistico tra l'ordine architettonico presente nella sala e le pareti dei cortili secondari, trattate semplicemente a bugnato.

La vista dell'Aula dei Deputati mostra, invece, come lo spazio, anch'esso sviluppato in altezza, risulti compresso e suggerisce il motivo del ripensamento progettuale nell'ampliamento di Palazzo Montecitorio, in cui l'attuale Camera dei Deputati è decisamente più ampia, grazie alla maggiore profondità dello spazio antistante la cavea.

Riguardo le tecniche di rappresentazione ci si è limitati ad una simulazione priva di cromatismi per la mancanza di informazioni materiche, assenti sia nei disegni, sia nelle memorie.

Si è inserita una luce solare sia per evidenziare gli effetti chiaroscurali dei fronti, sia per sottolineare la funzione dei grandi lucernari delle aule che consentono l'illuminazione zenitale. Per l'elaborazione delle viste prospettiche si è trasformato il modello CAD in modello poligonale, cercando un compromesso accettabile tra la necessità di riprodurre con completezza i partiti architettonici e contenere il numero dei poligoni per ridurre i tempi delle fasi computazionali dei rendering. A tal fine si è scelto di semplificare il calcolo della luce [IO] e i canali dei materiali [I l] avendo, però, come obiettivo, quello di non sacrificare la resa chiaroscurale. 
Fig. I I.Vista prospettica dell'Aula dei Deputati (modellazione e render di Davide Abbate; post produzione dell'autore)

Fig. 12. Spaccato prospettico della Sala delle Sedute reali

(modellazione e render di Irene Accurso; post produzione dell'autore)

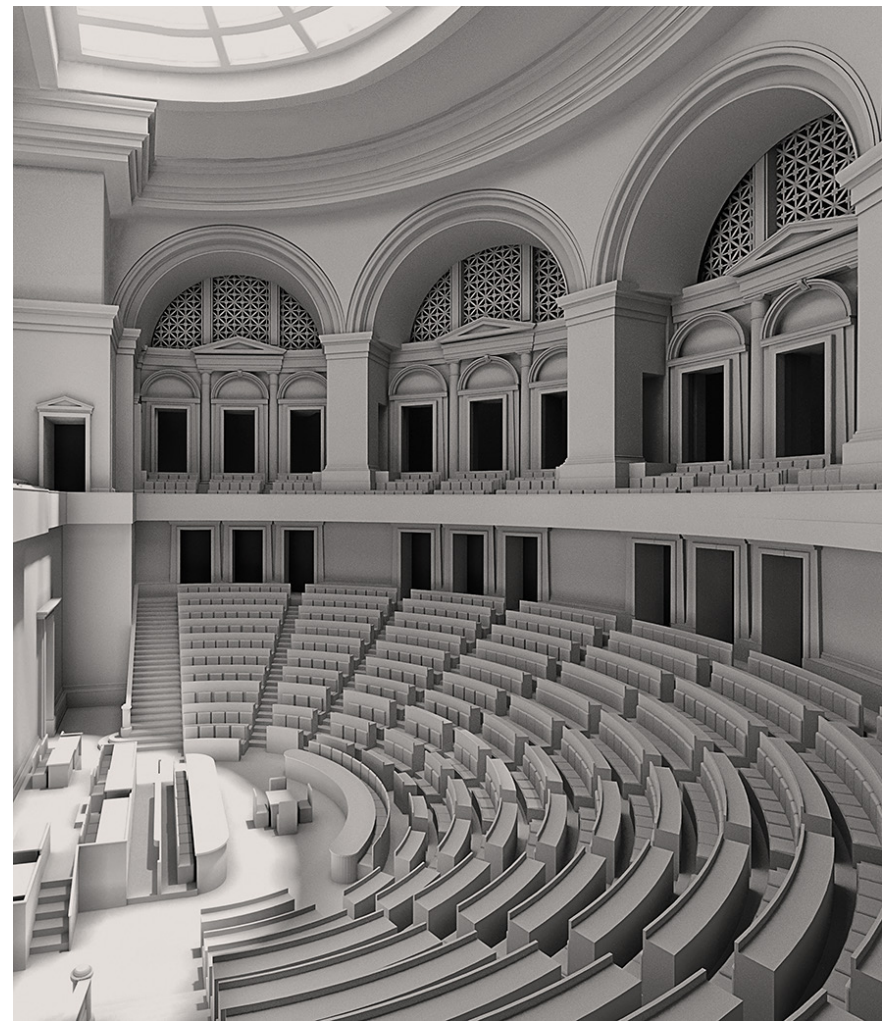

\section{Conclusioni}

Il progetto per il secondo concorso per il Parlamento è, probabilmente, il più maturo della fase dei concorsi romani. Rigore compositivo, controllo modulare, articolazione volumetrica perfettamente coerente con la struttura funzionale, interpretazione controllata del linguaggio classico, articolazione complessa degli spazi, trattamento monumentale dei fronti murari lo configurano come opera di un architetto capace di confrontarsi con la complessità di un progetto di grandi dimensioni e con un forte valore simbolico.

La descrizione grafica integra gli studi storici già effettuati servendosi del disegno come strumento di interpretazione, cercando di aggiungere informazioni e spunti per ulteriori ricerche. 


\section{Note}

[I] || concorso è vinto da Guglielmo Calderini (1837-1916)

[2] L'esito dei lavori è pubblicato sulla «Gazzetta Ufficiale» del 15 gennaio 1890 [Sessa 2002, pp. 378, 379].

[3] II sistema metrico decimale è stato adottato in seguito all'unità d'Italia nel |86|, e nel | 877 sono state pubblicate dalla Stamperia Reale di Roma le Tavole di comparazione dei pesi e delle misure in uso nelle varie provincie del Regno con quelle del sistema metrico decimale.

[4] Si è integrata la modellazione di solidi e di superfici NURBS.

[5] Sui criteri d'interpretazione nelle operazioni di ricostruzione congetturale [Apollonio 20 I6].

[6] Basile applica la regola canonica dell'ombra da fonte luminosa a distanza impropria inclinata di $45^{\circ}$ sia sul piano orizzontale che su quello verticale.

[7] L'ombra può rivelare una forma: si pensi al mito della fanciulla corinzia Diboutades, che disegna il profilo del suo amato grazie all'ombra proiettata su una parete [De Rosa 1997].

[8] Si veda: Mimesis, pictura, póiesis, in: Ugo 2002.

[9] Si veda: Mimesis, pictura, póiesis, in: Ugo 2002, p. II.

[ I0] Si è applicata la Global Illumination con parametri valutati in base a tempi di rendering ritenuti accettabili.

[I I] Ci si è limitati al canale diffuse con inserimento di ambient occlusion.

\section{Riferimenti bibliografici}

Apollonio Fabrizio Ivan (2016). Classification Schemes for Visualization of Uncertainty in Digital Hypothetical Reconstruction. In Münster Sander, Pfarr-Harfst Mieke, Kuroczyński Piotr, loannides Marinos (eds.). 3D Research Challenges in Cultural Heritage II. How to manage data and xnowlwdge related to interpretative Digital 3D reconstruction of cultural heritage. $\mathrm{Cham}(\mathrm{CH})$ : Springer pp. 73-98.

Basile Ernesto ( 1890$)$. Progetto per il palazzo del parlamento italiano nel concorso nazionale del 1889. Roma: Stabilimento Tip. Italiano.

De Rosa Agostino (1997). Geometrie dell'ombra. Storia e simbolismo della teoria delle ombre. Milano: Città studi edizioni.

de Rubertis Roberto (2002). Il disegno dell'Architettura. Roma: Carocci editore.

Fasolo Orseolo (Post 1955). Analisi grafica dei valori architettonici. Lezioni del Prof. Vincenzo Fasolo. Roma: Università di Roma.

Marsiglia Nunzio (20I5). La ricostruzione congetturale dell'architettura. Storia, metodi, esperienze applicative. Palermo: Graphill.

Pagnano Giuseppe (1975). La lettura critica: Analisi di cinque opere di Adolf Loos. Catania: Cavallotto Editore.

Mauro Eliana, Sessa Ettore (20 I5). I disegni della Collezione Basile. Roma: Officina Edizioni.

Mauro Eliana, Sessa Ettore (a cura di). (2000). Giovan Battista Filippo Basile ed Ernesto Basile: settant'anni di Architetture: i disegni restaurati della Dotazione Basile, 1859-1929. Palermo: Novecento.

Sessa Ettore (2002). Ernesto Basile. Dall'eclettismo classicista al modernismo. Palermo: Novecento.

Ugo Vittorio (2002). Fondamenti della rappresentazione architettonica. Bologna: Esculapio.

Autore

Fabrizio Avella, Università degli Studi di Palermo, fabrizio.avella@unipa.it

Per citare questo articolo: Il secondo concorso per il Parlamento di Ernesto Basile. Analisi e ricostruzione congetturale/The second competition for the Parliament of Ernesto Basile. Analysis and congectural reconstruction. In Arena A., Arena M., Brandolino R. G., Colistra D., Ginex G., Mediati D., Nucifora S., Raffa P. (2020). Connettere. Un disegno per annodare e tessere. Atti del $42^{\circ}$ Convegno Internazionale dei Docenti delle Discipline della Rappresentazione/ Connecting. Drawing for weaving relationships. Proceedings of the 42th International Conference of Representation Disciplines Teachers. Milano: FrancoAngeli, pp. 1622-1643. 


\title{
The Second Competition for the Parliament of Ernesto Basile. Analysis and Congectural Reconstruction
}

\author{
Fabrizio Avella
}

Abstract

The study is part of the sector of congectural reconstructions of projects based on archive drawings. In this case, it is Ernesto Basile's project for the second competition for the Parliament of the Kingdom of Italy, which ended in 1889. It is a very mature project, awarded ex aequo from the jury together with four others, and concludes the phase of the Roman competitions (1882-89), marked by a classicist language that permeates the projects for the institutional seats. The original drawings of the work, which was not realized, are kept in the Basile-Ducrot Endowment of the Department of Architecture of the University of Palermo, and have been used for surveying, vectorization, analysis and thanalisiree-dimensional modeling. Analytical models have been developed, to offer a graphic reading able to enucleate compositional aspects, and models with descriptive purposes in order to visualize spaces and volumes.

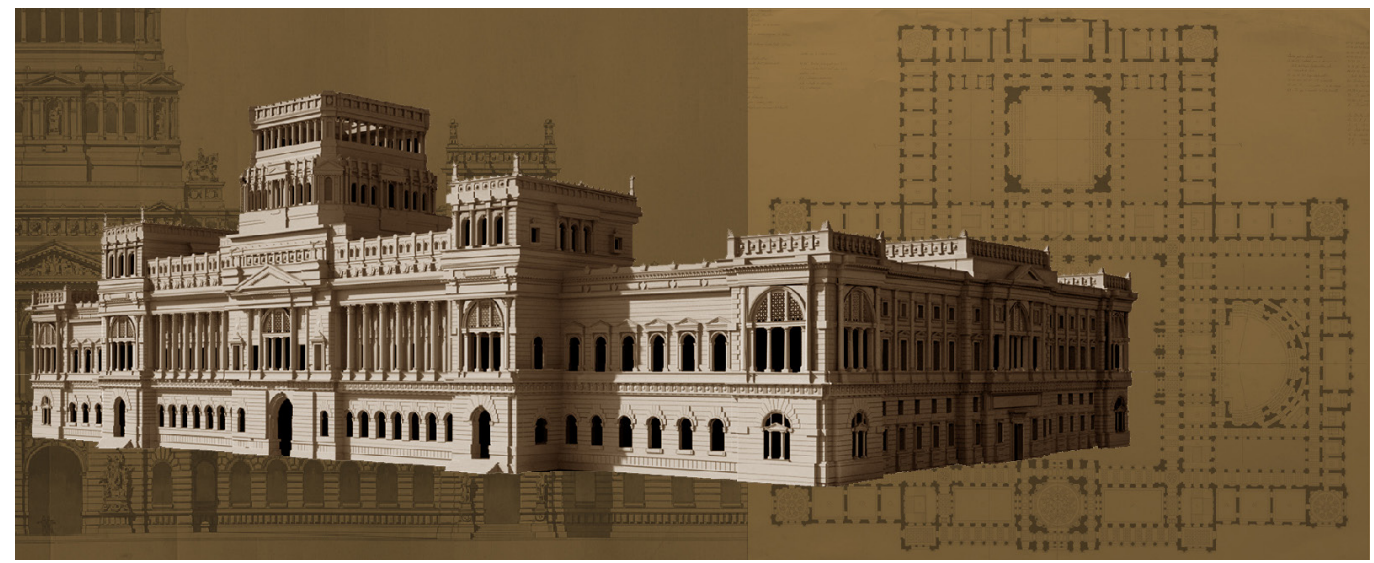




\section{Introduction}

The project for the second competition for the Parliament of the Kingdom of Italy (I 8881889) can be considered one of the most important of Ernesto Basile's production and is part of the Roman production of competition projects for the new institutional headquarters of the young Kingdom of Italy. Italy. The "modern classicism" [Sessa 2002] that characterizes them is declined, from time to time, according linguistic and functional needs.

Basile begins to confront himself, just twenty-six years old, with the complexity of the themes elaborating the project for the first competition for the Palazzo del Parlamento (I 883) in which he manifests a compositional control that amazes given his young age.

The following year he elaborated the project for the first competition for the Palace of Justice: permeated by a language inspired by the "completed expressive maturity" of the Florentine fifteenth century style [Mauro, Sessa 20 I5], it presents some planimetric asymmetries that will be resolved in subsequent projects.

In the projects for the second and third competitions for the Palace of Justice (I 885- I 886), in fact, the variation of the planimetric composition and the inspiration for a sixteenth-century classicism give light to articulated bodies with a design coherence that leads the Commission to select the project for the drafting of the fourth competition ( 1887 ). Here Basile overturns the compositional assumption and inserts a large central courtyard surrounded by galleries, tracing a solution that will be proposed again later.

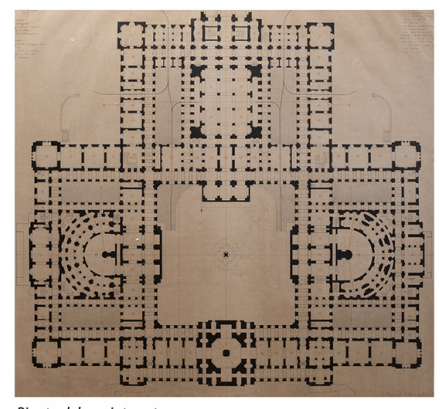

Pianta del seminterrato.
Matita, china, inchiostro e act

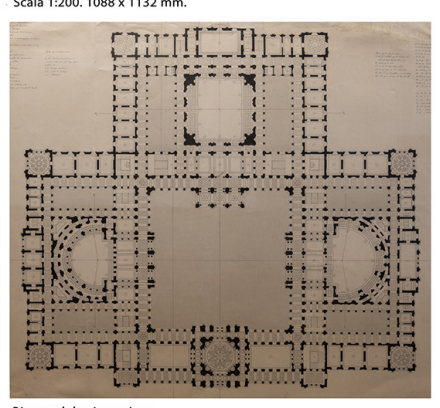

Pianta del primo piano.
Matita, china, inchiostroo

Matita, china, inchiostro e acq
Scala 1:200. $1043 \times 1134 \mathrm{~mm}$

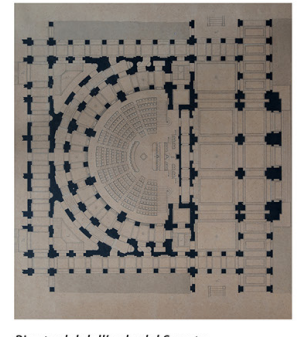

Pianta del dell'aula del Senato.

sucartonicio.
Scala $1: 100.758 \times 678 \mathrm{~mm}$.

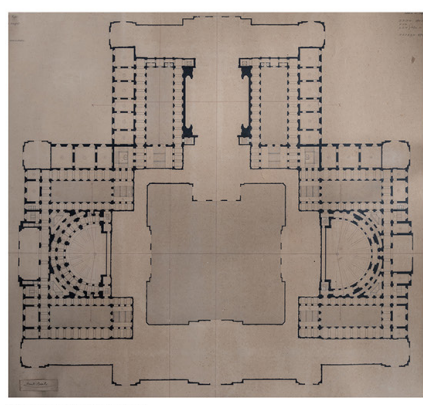

Pianta del piano terra. Matita, china, inchiostro e acquerello su cartoncino.
Scala 1:200. $973 \times 1095 \mathrm{~mm}$.

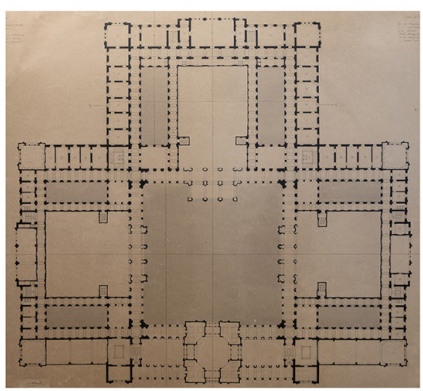

Pianta del secondo piano Matita, china, inchiosiltro e acquerello su cartoncino.
Scala 1:200.977 x 1157 man

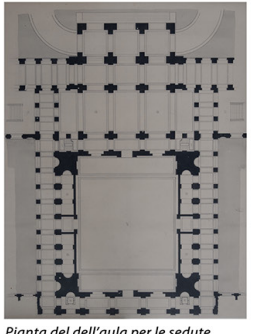

Pianta del dell'aula per le sedute reali.
Matita, china, inchiostro e aca
su cartoncino.

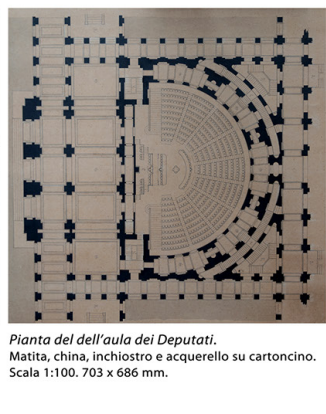


The project is not a winner [I], but the gained experience allows him to face the second competition for the Parliament (I888-| 889) with a design maturity that will be particularly appreciated by the jury.

The jury, chaired by Francesco Boschi, awards ex aequo the projects of Ernesto Basile, Luigi Broggi and Giuseppe Sommaruga, Gaetano Moretti, Pier Paolo Quaglia and Vincenzo Benvenuti, Enrico Ristori [2].

The project will not be carried out due to the political crisis following the fall of the government chaired by Francesco Crispi on January 31, I 89 I but presents, in an embryo, solutions that will be adopted in the expansion of Palazzo Montecitorio, which will engage Basile between 1903 and 1918.

The drawings of the second competition are conserved in the Basile Endowment of the Scientific Collections of the Department of Architecture of the University of Palermo, curated by Professor Ettore Sessa.

Already from a first observation we are impressed by the strong compositional rigor: a large central courtyard overlooked by the Chamber of Deputies and that of the Senate, arranged symmetrically with respect to the main axis, and the Royal Sittings Hall, which closes the courtyard along the main axis of symmetry.

The language used is inspired by a Renaissance classicism, very austere but appropriately articulated in the individual compositional solutions. The volumetry clearly highlights the compositional scheme and the treatment of the fronts is developed with extreme consistency with respect to the hierarchy of functions.

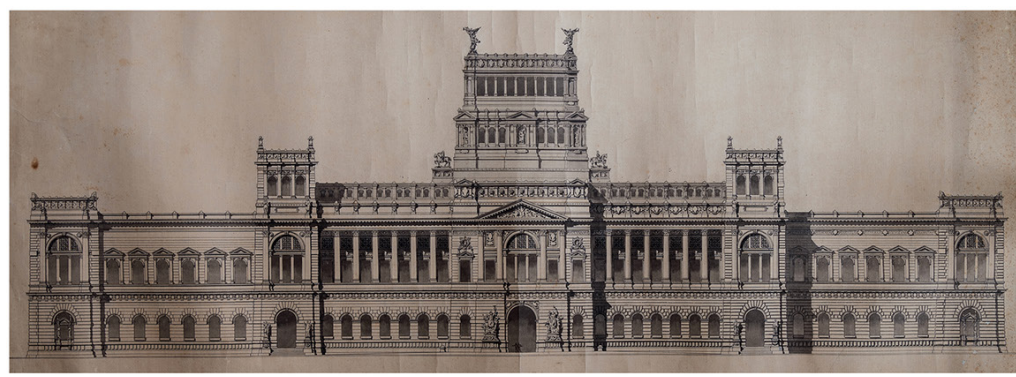

Prospetto principale.

Matita, china ed acquerello su cartoncino. Scala 1: $200.810 \times 1186 \mathrm{~mm}$.

Prospetti laterali.

Matita, china e acquerello su cartoncino. Scala 1:200. $928 \times 1181 \mathrm{~mm}$

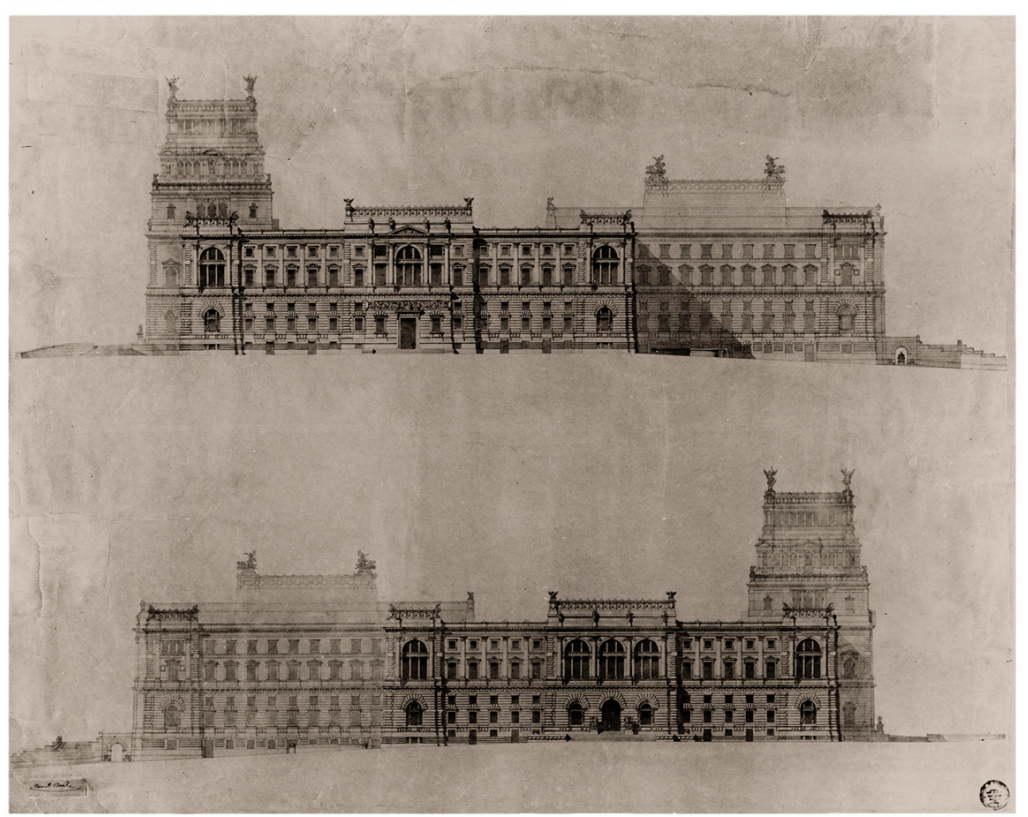




\section{Analysis of sources and vectorization}

The corpus of drawings contains I I large format plates, from 70.5 by $68.2 \mathrm{~cm}$ of the topographic frame to 81.0 by 187.6 of the main elevation. There are: a plan on a scale of I: I000; four plans on the various levels, inked on cardboard, on a scale of 1:200; three plans of the Chamber of Deputies, the Senate Chamber and the Royal Sitting Hall, inked on cardboard, on a scale of I: I00; the main elevation, in ink and watercolour scale I: I00; the rear elevation and the cross section, in pencil and ink on cardboard, scale 1:200; the side elevations, in pencil, ink and watercolour on cardboard, scale 1:200.

The analysis of the documentary sources showed that the available information allowed the reconstruction of the project and the parallel analysis process.

The flat scans of the drawings, provided by the Basile equipment, were used to carry out the direct survey to obtain dimensional, rough and detailed information relating to axes distances, modules, wall thicknesses, openings, moldings, necessary for correct model processing. Flat photogrammetry operations have subsequently allowed to correct the distortions, however small, of the scans.

The images obtained were subsequently used for flat vectorization, carried out in compliance with the units of measurement, without doubt those of the metric decimal system [3], already in use at the time of drawing up the project, and the modular scanning, not processed afterwards but considered essential for the correct sizing of the works: where the identification of a module was clear and unequivocal, in the presence of doubts arising from the information of the images, priority to positioning according to the modules was given.

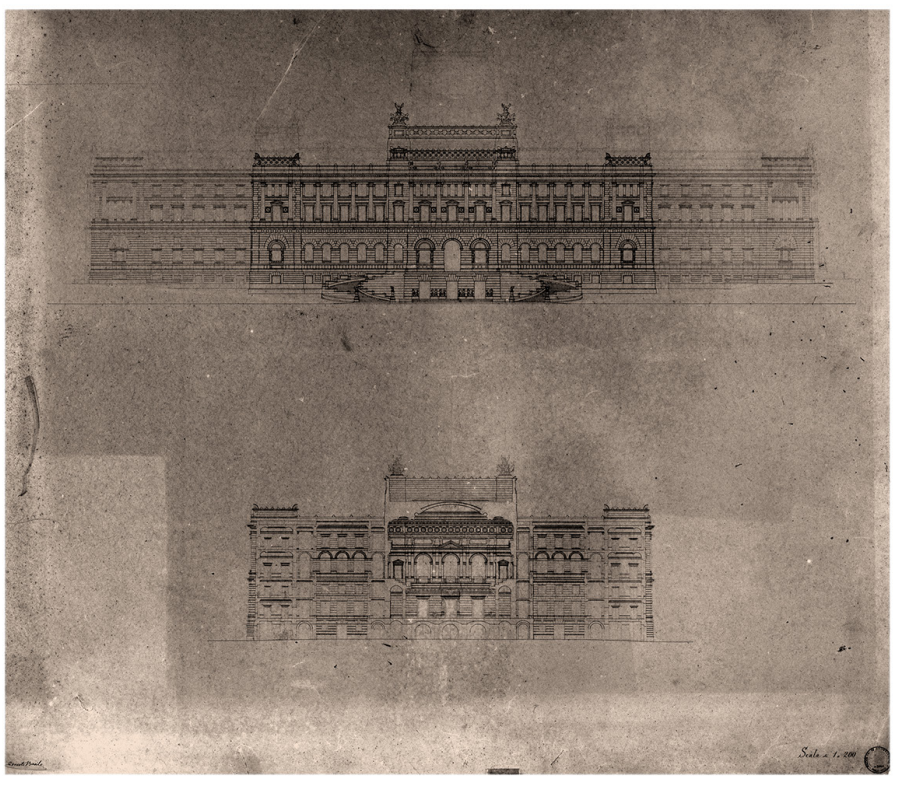

Prospetto posteriore
e sezione trasversale e sezione trasversale. Matita e china su cartoncino.
Scala 1:200. $1012 \times 1131 \mathrm{~mm}$.
Sezione longitudinale e sezione trasversale. Dal manifesto di presentazione del progetto.

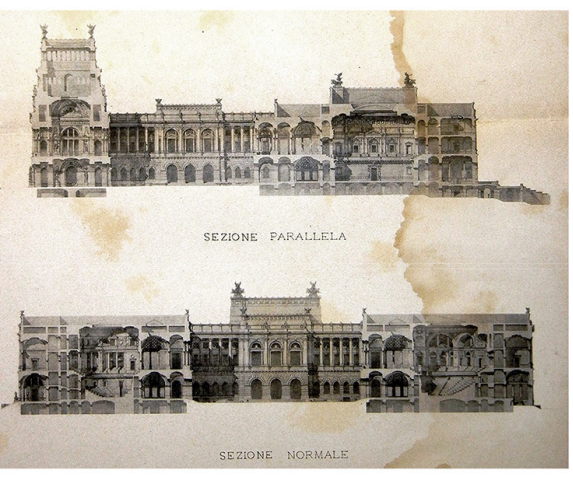




\section{Three-dimensional modeling interpretation criteria}

The three-dimensional model construction [4] took into due consideration the positioning of the compositional axes, the planimetric and altimetric alignments of the wall compartments and openings, as well as the scores of the classical order; in some cases, even if the iconographic documentation was certainly extensive and detailed, logical-deductive interpretation criteria were made in case of lack of information [5].

For the Royal Sitting Hall, for example, in the absence of a roof plan, the configuration of the top skylight was unclear: a rectangular shape was assumed at first, considered congruent with the layout of the room, but the observation of the section transversal highlighted an elliptical projection of the shadow, which allowed to hypothesize the circular shape of the summit hole with few margins of doubt [6]. The shadow was therefore a revealing presence of the shape [7].

Another problem of interpretation has come in the construction of the interior front of the Chamber of Deputies. There are not drawings in which it is visible, but it is possible to formulate a configuration hypothesis taking inspiration from the planimetric traces and the adjoining rooms morphology. The tripartite vestibule is covered by raised cross vaults, which are set on the perimeter walls with large arches: it is therefore conceivable that these arches correspond to similar ones on the opposite side of the wall facing, whose radius can be deduced from the position of the columns and half-columns. The positioning of the three arches above the trabeation that runs inside the Chamber of Deputies defines the front configuration congruent with that one of both the hall and the vestibule. The theme of the three-arched wall is, moreover, developed in the final project and is visible in today's configuration of the Chamber of Deputies. The proposed solution, therefore, is plausible in the present state of knowledge.

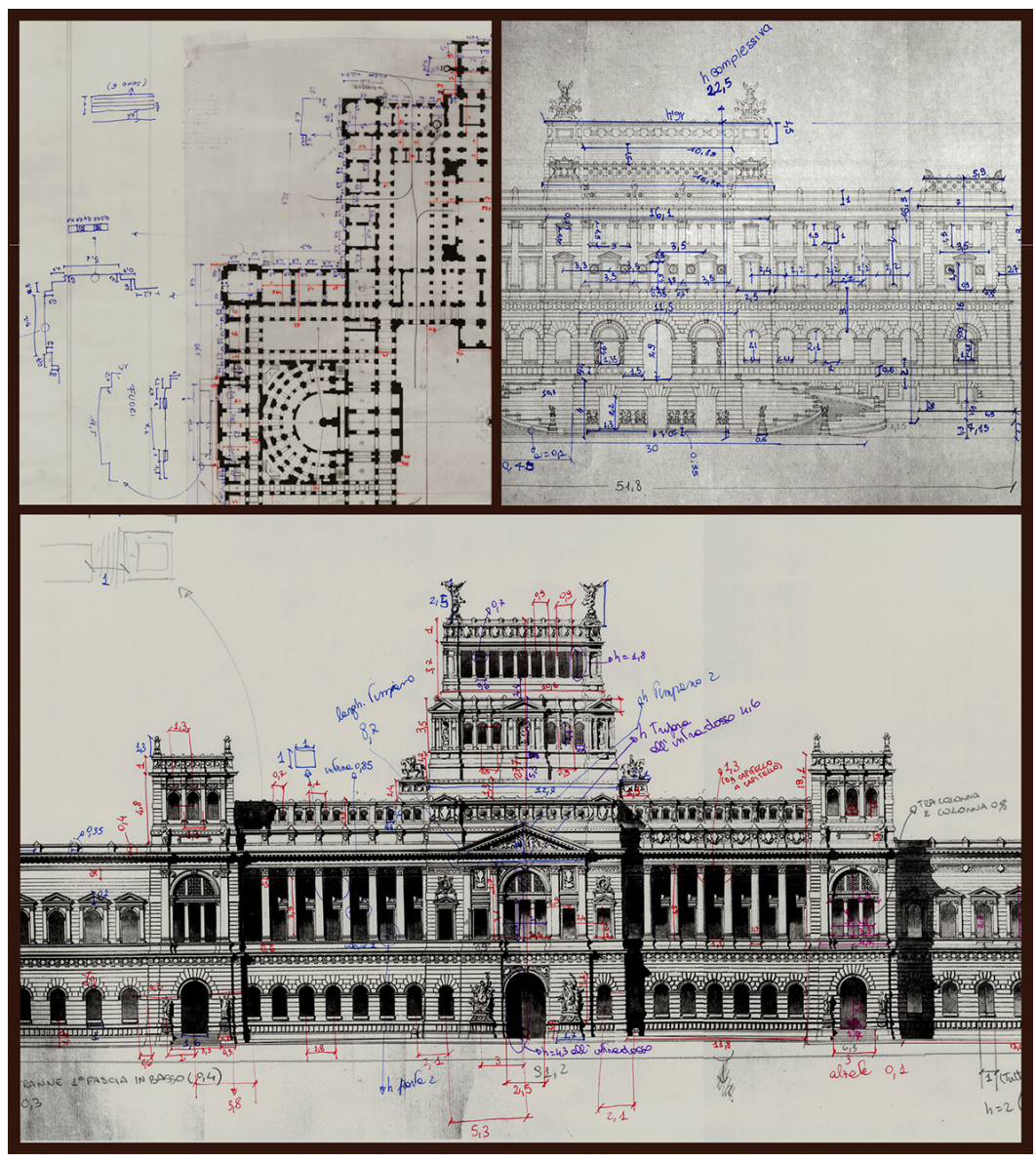


Other missing information relates to the front of the courtyard behind the entrance: the front corresponding to the Royal Sittings Hall is visible in what Basile calls "Normal section", the one in front of the Senate Hall is visible in the "Parallel section" and the Hall of the Deputies one can be deduced thanks to the perfect symmetry of the building, but there are no drawings of the one behind the entrance.

There is, however, valuable information that can be deduced from the plans and sections: the tower front of the main entrance presents, both in the plans and in the longitudinal section, a perfect mirror symmetry that makes the construction of the front on the courtyard plausible by analogy; the colonnaded wings that flank it can be treated like those visible in the original sections of the courtyard, completely analogous to those of the main front, and there is no reason to hypothesize any variations.

\section{Analytical descriptions}

The drawings with analytical function allow what Giuseppe Pagnano calls "critical reading" of a project [Pagnao 1975]. Architecture is taken as an expressive language and interpretation as a metalanguage: "Considering architecture as a set of signs, it is possible to [...] define drawing as an applied language, as a metalanguage of architecture" [Pagnano 1975, p. 7]. The representation has, in this case, a high symbolic content [de Rubertis 2002], "with analytical-informative or semiotic-communicative value" [8], and dissociates some components and then reassembles them in synthetical images: "In critical reading, the decomposition is carried out using the graphic tool; therefore it is the graphic image of the object that is dissociated into partial images" [9].

As already mentioned, the compositional scheme is based on the juxtaposition of three bodies, containing the Chambers, around the central courtyard according to a rigorous mirror symmetry along the longitudinal axis. The system is connected by main and secon-

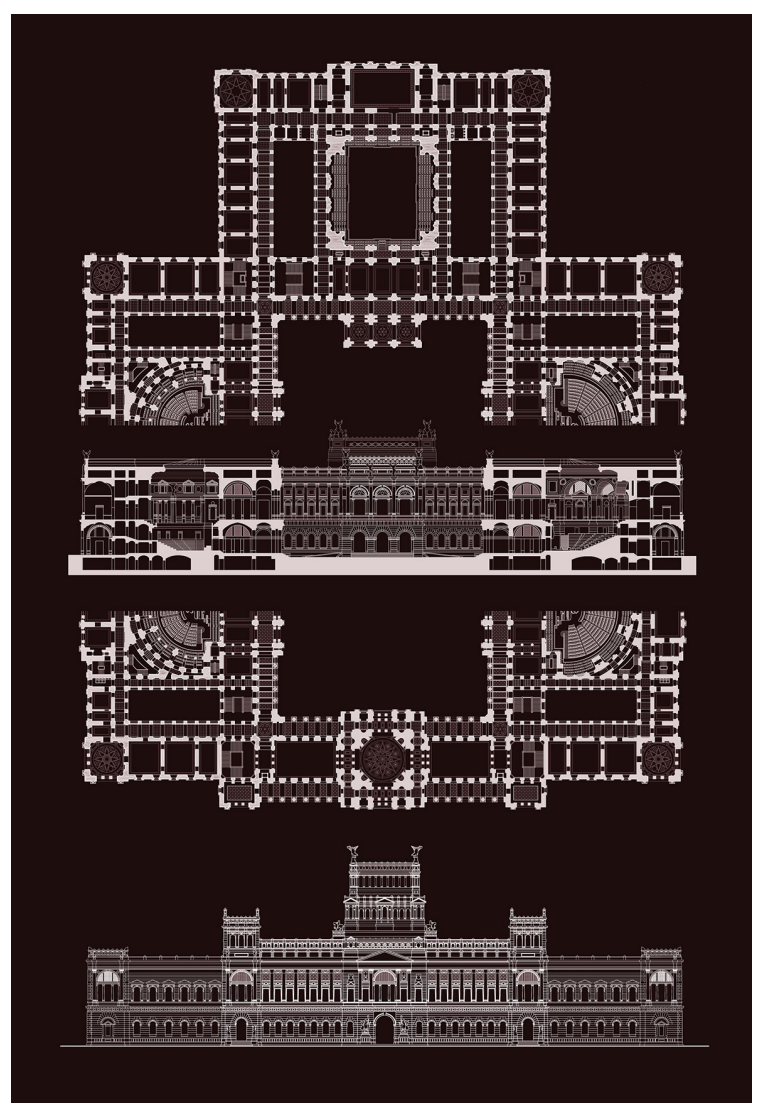




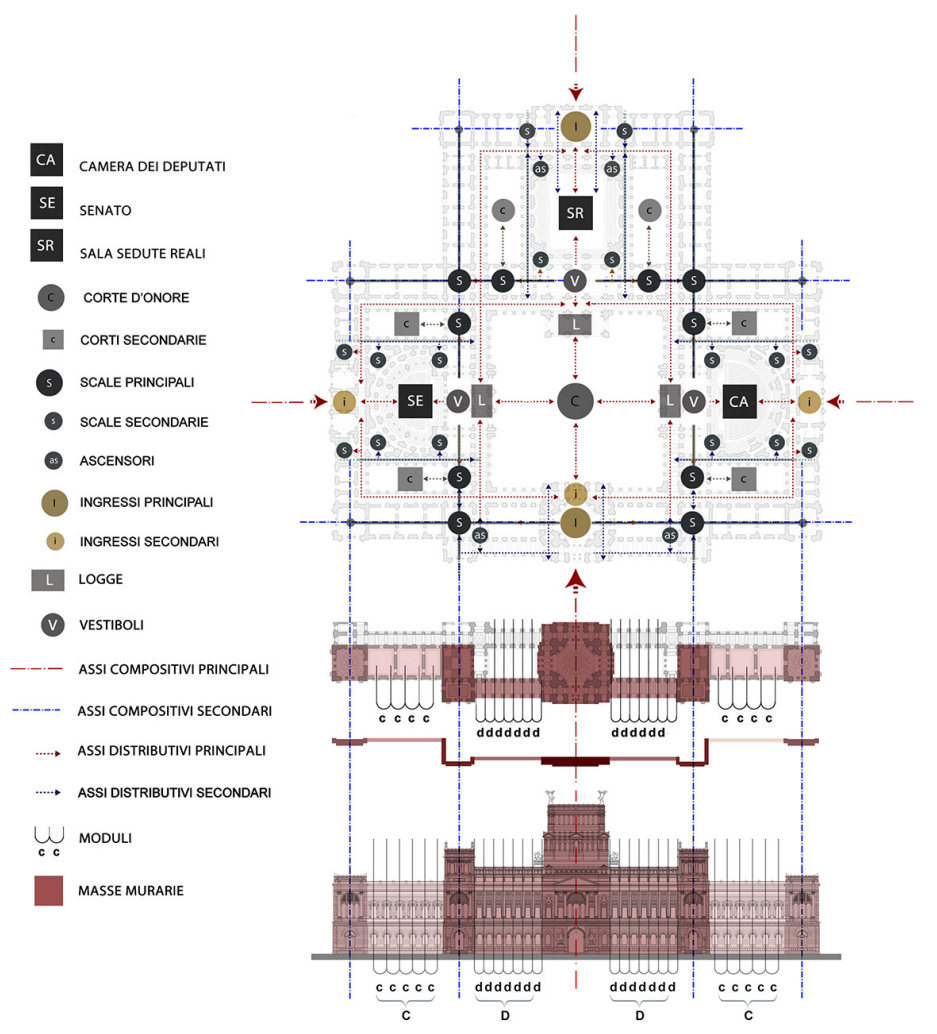

Fig. 6. Analysis of
functions, paths, modules and wall masses.

MASSA PRIMARIA
IN PRIMA PROIEZIONE MASSA SECONDARIA MASSA SECONDARIA
IN PRIMA PROIEZIONE MASSA TERZIARIA IN

MASSA SECONDRIA IN
SECONDA PROIEZIONE MASSA TERZIARIA IN
SECONDA PROIEZIONE

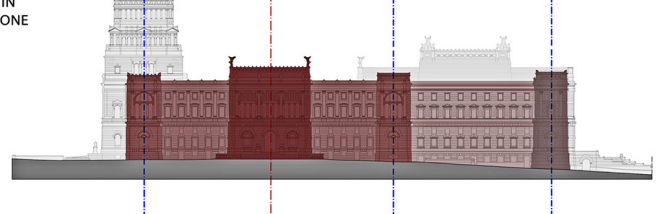


Fig. 8. Perspective view of the main front (modelin and rendering by Carla Verace; post production by the author).

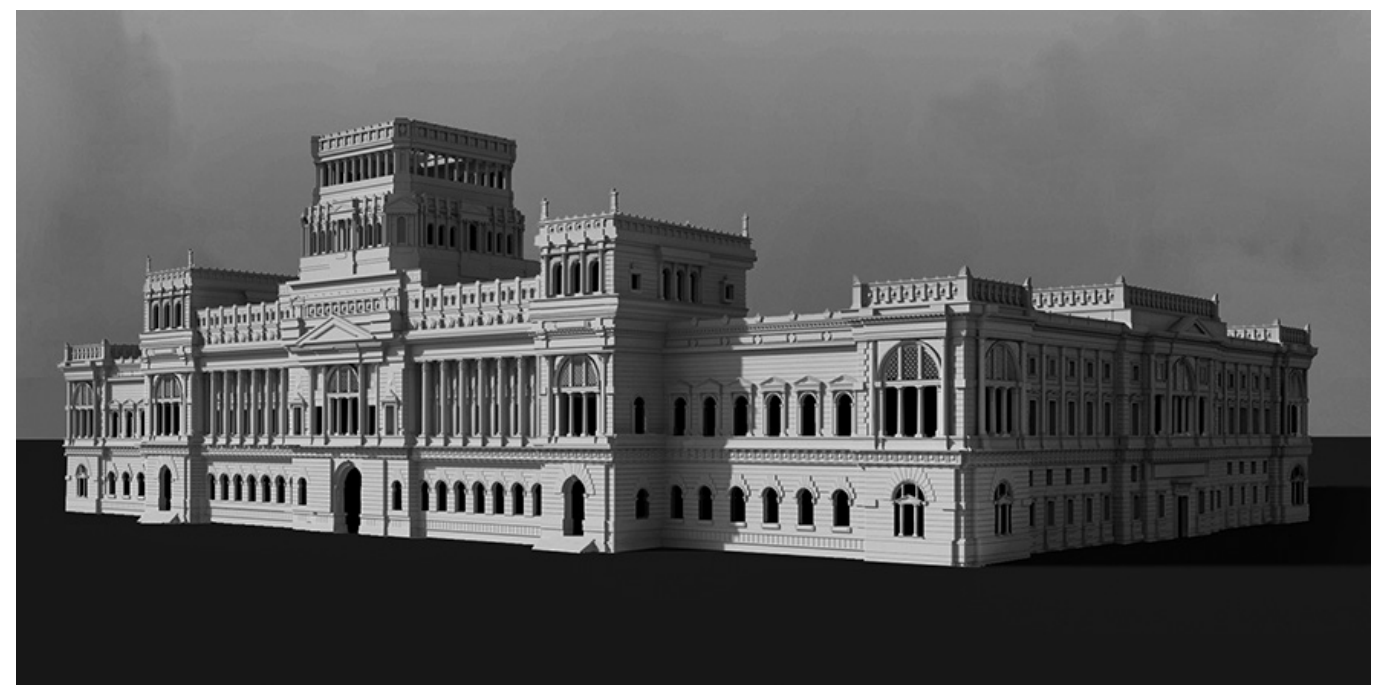

dary distribution axes that connect the rooms, the courtyard and the accessory functions. The whole composition is controlled by main and secondary axes of symmetry and by a rigorous modular system.

In correspondence with the Chambers there are double logging subsystems that overlook the courtyard, while the main and secondary ascent systems are at the intersection of the distribution axes.

The functional structure is revealed with extreme consistency by the volumetric parties. The main front is divided vertically: the front tower of the entrance, which only has the role of marking the building at an urban level, is flanked by two colonnaded wings closed by corner towers, placed at the intersection of the lateral wings that host accessory functions.

The latter act as a hinge with the lateral fronts, also characterized by slightly projecting foreparts in correspondence of the Chambers, flanked by windowed wings with giant order. The presence of the Chambers is underlined, on all fronts, as well as by the slight overhang, by a greater elevation and by the more developed attic wall in height.

The rear front is characterized by the protrusion of the volume of the Royal Sitting Hall and is articulated, like the main front, in two wings with giant pilasters at the level of the classroom closed by corner towers. The hierarchically dominant role of the classroom is underlined by the monumental pincer staircase.

The fronts of the courtyard also report the presence of the Chambers thanks to overhangs in correspondence with the access loggias.

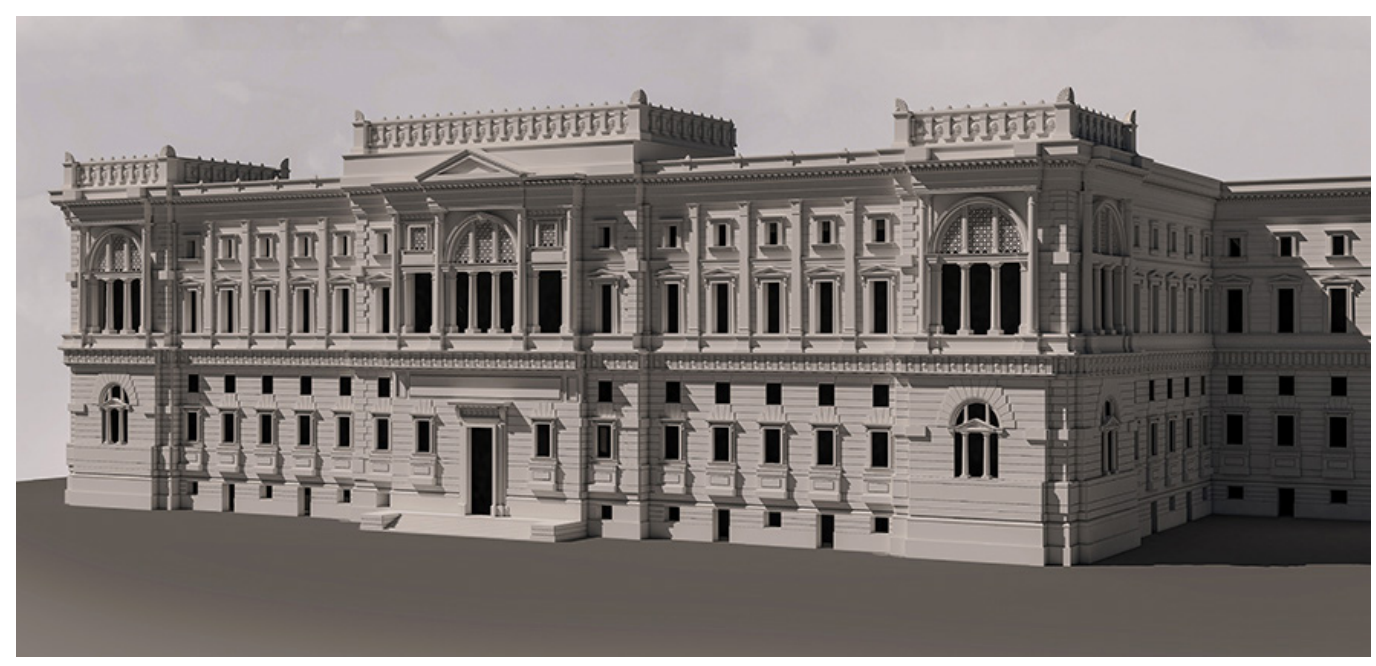

Fig. 9. Perspective view Chamber of Deputies (modeling and rendering by Davide Abbate: post production by the author). 
The entire wall perimeter is treated according to a very strong hierarchical system: the front is treated with the monumental emphasis that the entrance system to the main institution of the country deserves, the two lateral fronts show the political equivalence of the Chamber of Deputies and the Senate Hall, while the rear front emphasizes the presence of the Royal Sittings Hall.

Fig. 10. Perspective view of the rear face (modeling and renderin by Irene Accurso; post author).

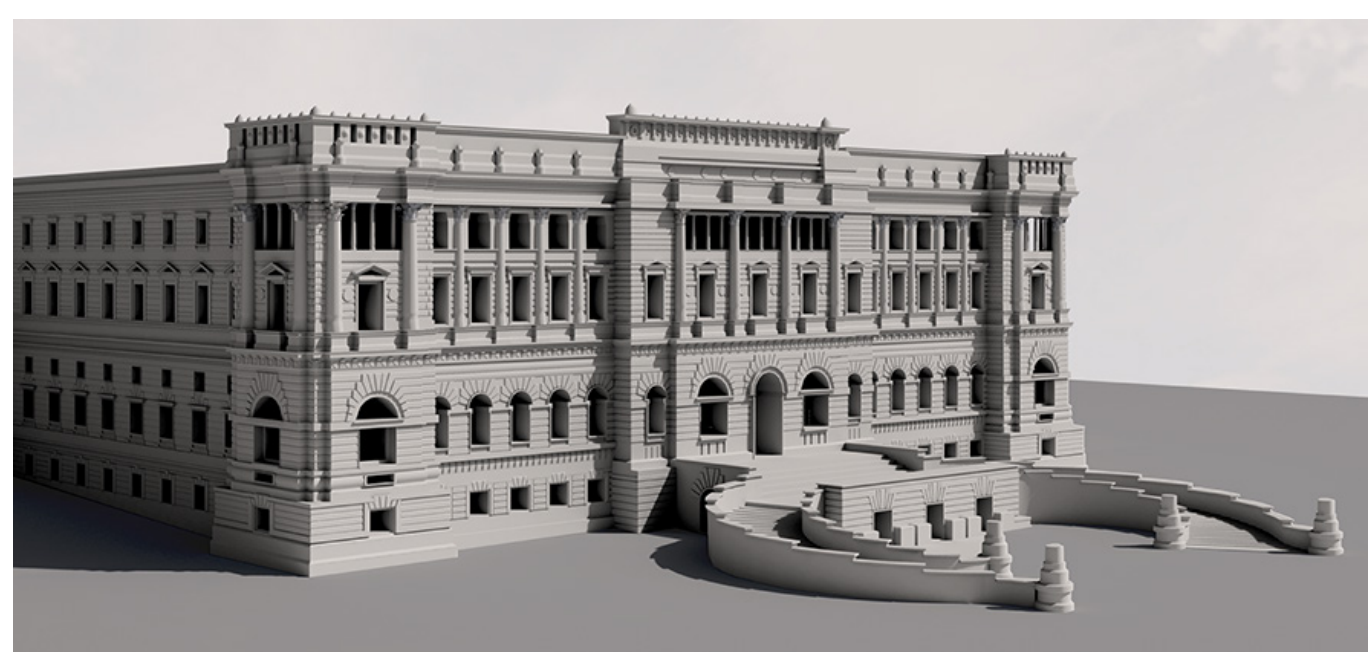

\section{Perspective views and representation techniques}

The corpus of the drawings does not present perspective views, unlike the competition documents for the Justice Palace. The lack is to be underlined, given that Basile, in all his design activity, often makes use of them. The reconstruction of the model allowed, therefore, to visualize the spaces and the volumetric variations of the fronts.

We have chosen to carry out vertical frame perspectives, with varying viewpoint heights. The perspectives of the exteriors make us appreciate the strong sense of monumentality that characterizes the building of the politically most prestigious institution in the Kingdom, as well as the skilful articulation of projections and retractions that manifest the functional hierarchies on the outside.

The perspective cross-section on the Royal Seating Room makes you appreciate both the space, developed on a quadruple height, and the linguistic comparison between the architectural order present in the room and the walls of the secondary courtyards, simply treated with ashlar.

The view of the Chamber of Deputies shows, instead, how the space, also developed in height, appears compressed and suggests the reason of a rethinking in the extension design of Palazzo Montecitorio, in which the current Chamber of Deputies is definitely more wide, thanks to the greater depth of the space in front of the auditorium.

Regarding the representation techniques, we limited ourselves to a simulation without chromatisms due to the lack of material information, absent both in the drawings and in the memories.

A solar light was inserted both to highlight the chiaroscuro effects of the fronts and to underline the function of the large skylights of the halls that allow zenithal illumination.

For the elaboration of the perspective views, the CAD model has been transformed into a polygonal one, seeking an acceptable compromise between the need to completely reproduce the architectural parties and contain the number of polygons, in order to reduce the time of the rendering computational phases. For this purpose, we have chosen to simplify the calculation of light [10] and the channels of the materials [I I], having, however, as objective, not to sacrifice the chiaroscuro rendering. 
Fig. I I. Perspective view of the Chamber of Deputies (modeling and rendering by Davide Abbate: post production by the author).

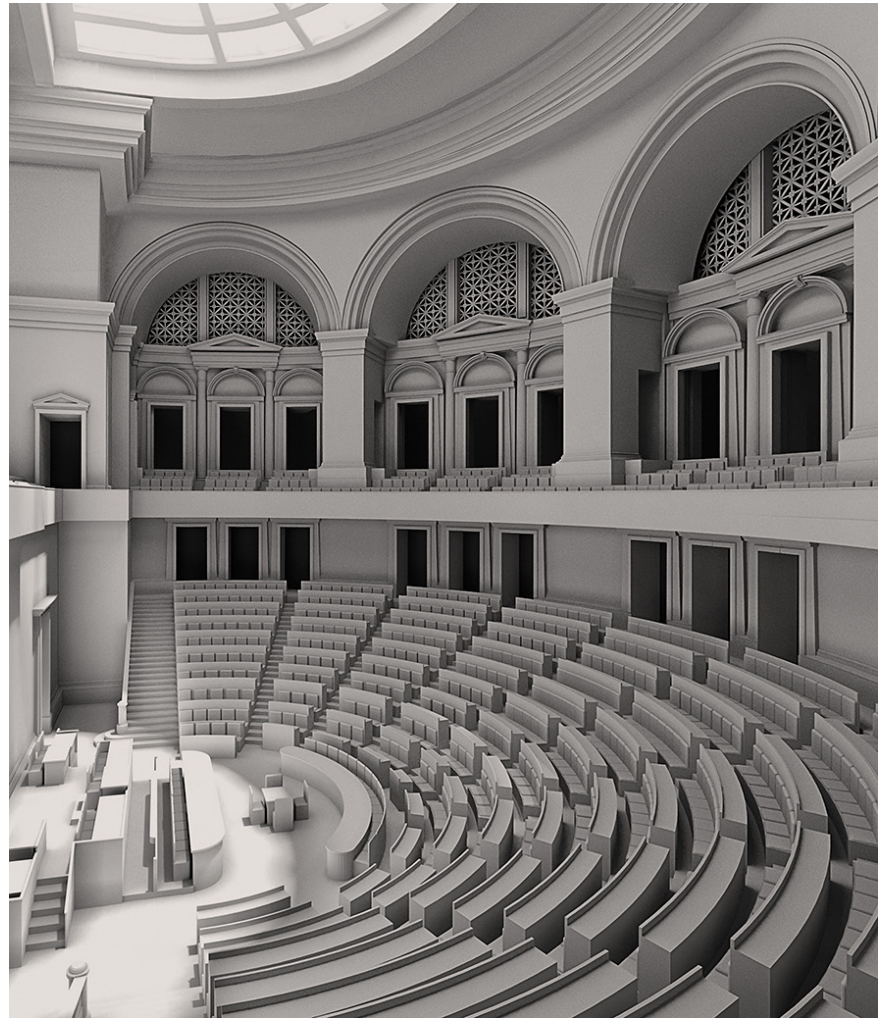

\section{Conclusions}

The plan for the second competition for Parliament is probably the most mature in the Roman competition phase. Compositional rigor, modular control, volumetric articulation perfectly consistent with the functional structure, controlled interpretation of the classical language, complex articulation of the spaces, monumental treatment of the wall fronts configure it as the work of an architect capable of dealing with the complexity of a large project and with a strong symbolic value.

The graphic description integrates the historical studies already carried out using drawing as an interpretation tool, trying to add information and ideas for further research.

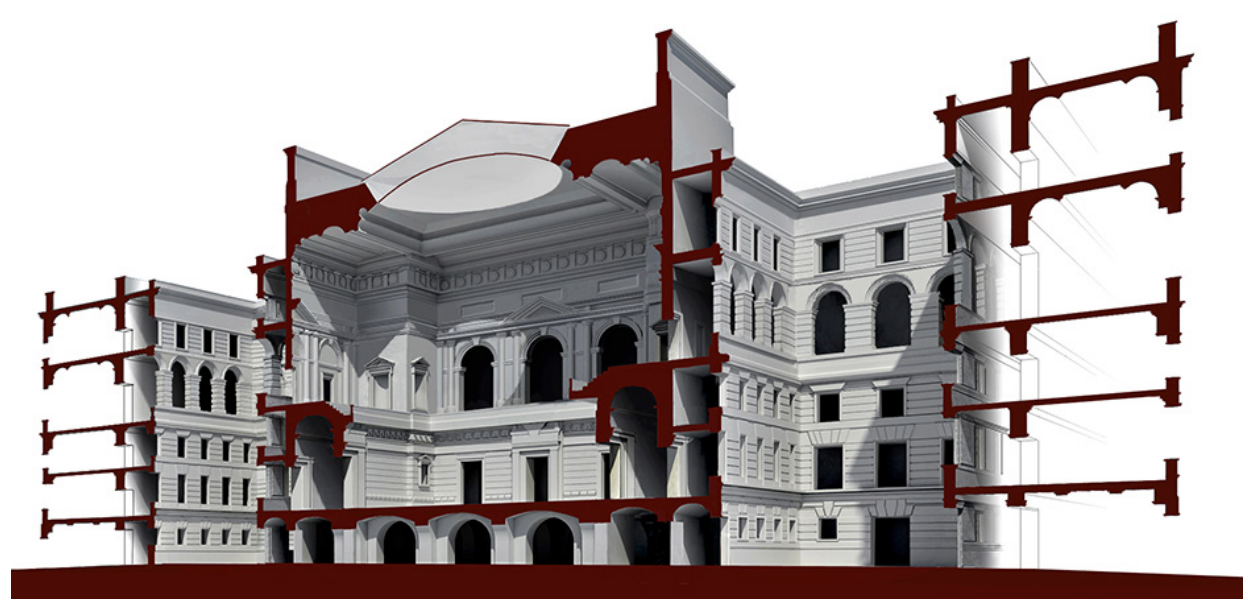




\section{Notes}

[I]The competition is won by Guglielmo Calderini (|837-19|6).

[2] The outcome of the work of the Examining Commission is published in the «Gazzetta Ufficiale» of January I5, I 890: [Sessa 2002, pp. 378, 379].

[3] The metric decimal system was adopted after the unification of Italy in I86 I, and in 1877 the Tables comparing the weights and measures in use in the various provinces of the Kingdom with those of the metric system were published by the Stamperia Reale di Roma.

[4] CAD modeling has integrated solid and NURBS models.

[5] About interpretation criteria in conjectural reconstruction operations, cf. Apollonio (20 I 6).

[6] Basile applies the canonical rule of shadow from a light source at an improper distance inclined by $45^{\circ}$ on the horizontal and vertical planes.

[7] The shadow can reveal a shape: think of the myth of the Corinthian girl Diboutades, who draws the profile of her beloved thanks to the shadow projected on a wall: [De Rosa 1997].

[8] See: Mimesis, pictura, póiesis, in: Ugo 2002.

[9] See: Mimesis, pictura, póiesis, in: Ugo 2002, p. II.

[10] Global Illumination was applied with parameters assessed on the basis of acceptable rendering times.

[I I] We limited ourselves to the channel diffuse with the inclusion of ambient occlusion.

\section{References}

Apollonio Fabrizio Ivan (2016). Classification Schemes forVisualization of Uncertainty in Digital Hypothetical Reconstruction In Münster Sander, Pfarr-Harfst Mieke, Kuroczyński Piotr, loannides Marinos (eds.). 3D Research Challenges in Cultural Heritage II. How to manage data and xnowlwdge related to interpretative Digital 3D reconstruction of cultural heritage. $\mathrm{Cham}(\mathrm{CH})$ : Springer, pp. 73-98.

Basile Ernesto ( 890$)$. Progetto per il palazzo del parlamento italiano nel concorso nazionale del 1889. Roma: Stabilimento Tip. Italiano.

De Rosa Agostino (1997). Geometrie dell'ombra. Storia e simbolismo della teoria delle ombre. Milano: Città studi edizioni.

de Rubertis Roberto (2002). Il disegno dell'Architettura. Roma: Carocci editore.

Fasolo Orseolo (Post 1955). Analisi grafica dei valori architettonici. Lezioni del Prof. Vincenzo Fasolo. Roma: Università di Roma.

Marsiglia Nunzio (20I5). La ricostruzione congetturale dell'architettura. Storia, metodi, esperienze applicative. Palermo: Graphill.

Pagnano Giuseppe (1975). La lettura critica:Analisi di cinque opere di Adolf Loos. Catania: Cavallotto Editore.

Mauro Eliana, Sessa Ettore (2015). I disegni della Collezione Basile. Roma: Officina Edizioni.

Mauro Eliana, Sessa Ettore (a cura di). (2000). Giovan Battista Filippo Basile ed Ernesto Basile: settant'anni di Architetture: $i$ disegni restaurati della Dotazione Basile, 1859-1929. Palermo: Novecento.

Sessa Ettore (2002). Ernesto Basile. Dall'eclettismo classicista al modernismo. Palermo: Novecento.

Ugo Vittorio (2002). Fondamenti della rappresentazione architettonica. Bologna: Esculapio.

\section{Author}

Fabrizio Avella, Università degli Studi di Palermo, fabrizio.avella@unipa.it

To cite this chapter. II secondo concorso per il Parlamento di Ernesto Basile. Analisi e ricostruzione congetturale/The second competition for the Parliament of Ernesto Basile. Analysis and congectural reconstruction. In Arena A., Arena M., Brandolino R.G., Colistra D., Ginex G., Mediati D., Nucifora S., Raffa P. (2020). Connettere. Un disegno per annodare e tessere. Atti del $42^{\circ}$ Convegno Internazionale dei Docenti delle Discipline della Rappresentazione/ Connecting. Drawing for weaving relationships. Proceedings of the 42th International Conference of Representation Disciplines Teachers. Milano: FrancoAngeli, pp. $1622-1643$ 